This is the peer-reviewed version of the following article:

Trmcic, M. and Chadbourne, F.L. and Brear, P.M. and Denny, P.W. and Cobb, S.L. and Hodgson, D.R.W., 2013. Aqueous synthesis of N,S,-dialkylthiophosphoramidates: design, optimisation and application to library construction and antileishmanial testing. Organic and biomolecular chemistry. 11, 2660-2675. http://doi.org/10.1039/c3ob27448a

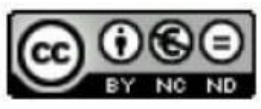

This work is licensed under a Creative Commons - Attribution-Noncommercial-No Derivative Works 3.0 Serbia 


\section{Durham Research Online}

\section{Deposited in DRO:}

09 May 2013

\section{Version of attached file:}

Accepted Version

Peer-review status of attached file:

Peer-reviewed

\section{Citation for published item:}

Trmcic, M. and Chadbourne, F.L. and Brear, P.M. and Denny, P.W. and Cobb, S.L. and Hodgson, D.R.W. (2013) 'Aqueous synthesis of N,S,-dialkylthiophosphoramidates : design, optimisation and application to library construction and antileishmanial testing.', Organic and biomolecular chemistry., 11 (16). pp. $2660-2675$.

Further information on publisher's website:

http://dx.doi.org/10.1039/c3ob27448a

Publisher's copyright statement:

Additional information:

Use policy

The full-text may be used and/or reproduced, and given to third parties in any format or medium, without prior permission or charge, for personal research or study, educational, or not-for-profit purposes provided that:

- a full bibliographic reference is made to the original source

- a link is made to the metadata record in DRO

- the full-text is not changed in any way

The full-text must not be sold in any format or medium without the formal permission of the copyright holders.

Please consult the full DRO policy for further details. 


\title{
Aqueous Synthesis of $N, S$-Dialkylthiophosphoramidates: Design, Optimisation and Application to Library Construction and Antileishmanial Testing
}

\author{
Milena Trmčić, ${ }^{a}$ Frances L. Chadbourne, ${ }^{a}$ Paul M. Brear, ${ }^{a}$ Paul W. Denny, ${ }^{b}$ Steven L. Cobb ${ }^{a}$ and David \\ R. W. Hodgson* $a$
}

\author{
Received (in XXX, XXX) Xth XXXXXXXXX 20XX, Accepted Xth XXXXXXXXX 20XX \\ DOI: $10.1039 / b 000000 x$
}

\begin{abstract}
We recently reported the use of $\mathrm{PSCl}_{3}$ for the thiophosphorylation of alkylamines where the resulting $N$ 10 thiophosphoramidate ions could be readily $S$-alkylated (Chem. Commun., 2011, 47, 6156-6158.). Herein we report the development of this methodology using amino acid, amino sugar, aminonucleoside and aniline substrates. The hydrolysis properties of $N$-thiophosphoramidate ions and their reactivities towards alkylating agents are also explored. In addition, we demonstrate the application of our approach to the preparation of a small library of compounds, including quinoline-based $N, S$-dialkylthiophosphoramidates 15 which were tested for antileishmanial activity.
\end{abstract}

\section{Introduction}

Phosphate esters are key intermediates in the transmission of genetic material and many other critical cellular processes. Structural analogues of these systems have been used widely as 20 tools for determining enzyme mechanisms and as inhibitors or activators of these enzymes. Sulfur-based analogues have been used in place of phosphodiesters to both increase and decrease the rate of ester bond cleavage. Accelerated cleavage rates are offered by $S$-bridging systems, ${ }^{1}$ where the thiolate leaving group 25 departs more readily than its alkoxide analogue, whereas reduced cleavage rates are seen for non- $S$-bridging systems. ${ }^{2}$ Nitrogenbridging phosphodiester mimics, where $N$-protonation becomes possible, have also been generated and studied. ${ }^{3-10}$ A combination of $N$ - and $S$-bridging systems have seen application in the form of 30 phosphate triester mimics that show antiviral activity. These uncharged, nucleoside-based thiophosphoramidates serve as prodrogs which traverse cell membranes, however, within the cell, programmed hydrolysis occurs to reveal nucleoside monophosphates that go on to interefere with viral replication.

35 Recently, we reported a simple aqueous method for the preparation of $N, \quad S$-thiophosphoramidates. ${ }^{11} \quad$ These phosphodiester mimics, with their $N$ - and $S$-bridges, were assembled through the electrophilic action of the reactive phosphorylating agent $\mathrm{PSCl}_{3}$ on nucleophilic primary 40 alkylamines followed by $S$-alkylation of the resulting $\mathrm{N}$ thiophosphoramidate ions - an approach that builds on our established use of reactive $\mathrm{P}$ species in aqueous systems. ${ }^{12-14}$ Here we describe the development of our strategy for aminothiophosphorylation, including the use of alkyl, aryl, amino 45 acid, amino-sugar and aminonucleoside substrates. We describe kinetic studies on the $\mathrm{pH}$-dependent hydrolysis properties of $\mathrm{N}$ - thiophosphoramidate ions which were used to inform subsequent optimisation of $S$-alkylation steps. Studies on several $S$-reactive electrophile species and alkylation conditions are also reported, 50 along with our efforts towards using bromoacetamides as generic amine-derived alkylating agents. Finally, our thiophosphorylation-alkylation conditions were applied to a library of lipophilic amines which were then alkylated with a quinoline derivative before being screened for activity against ${ }_{55}$ Leishmania mexicana, a causative agent of the Neglected Tropical Disease leishmaniasis. ${ }^{15}$

\section{Combined thiophosphorylation- $S$-alkylation of alkyl-, aryl- and biomolecule-derived amines.}

We demonstrated that simple alkylamines are effective substrates 60 for $\mathrm{PSCl}_{3}$ under aqueous conditions in the presence of $\mathrm{NaOH}$. The resulting $N$-thiophosphoramidate ions can then be alkylated effectively using a range of soft alkylating agents (Scheme 1).

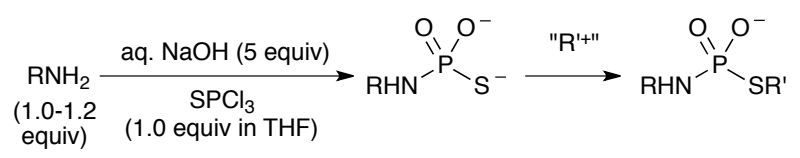

Scheme 1 Aqueous $N$-thiophosphorylation and $S$-alkylation.

${ }_{65}$ With the aim of broadening the scope of amine substrate used in this method we explored the thiophosphorylation and $S$-alkylation of aniline, unprotected phenylalanine, glucosamine and two 5'amino-5'-deoxynucleosides.

Aniline

70 We employed a 1.2:1 ratio of aniline 1 to $\mathrm{PSCl}_{3}$ followed by alkylation of the expected $N$-thiophosphoramidate ion using bromoethanol (Scheme 2). Thiophosphorylation proceeded to a 
reasonable extent of $62 \%$ as determined by ${ }^{31} \mathrm{P} \quad \mathrm{NMR}$ spectroscopy, with the key signal for thiophosphorylated amines usually appearing in the shift range 40-45 ppm. After addition of bromoethanol, a combination of ${ }^{1} \mathrm{H}$ and ${ }^{31} \mathrm{P}$ NMR methods 5 revealed $\sim 47 \%$ conversion to the $N, S$-thiophosphoramidate 2 ( $\delta \sim$ $20-25 \mathrm{ppm})$, and $32 \%$ of $S$-alkylated thiophosphate ion $3(\delta \sim 15-$ $20 \mathrm{ppm})$. The remainder of the product mixture was predominantly aniline $1(19 \%)$. The use of higher concentrations of aniline may have improved conversion to the $\mathrm{N}$ 10 thiophosphoramidate, and our studies with morpholine have shown that despite the increased potential for bis- and trisaminolysis of $\mathrm{PSCl}_{3}$, this is likely possible. However, on the basis of this preliminary result, we did not pursue this optimisation.

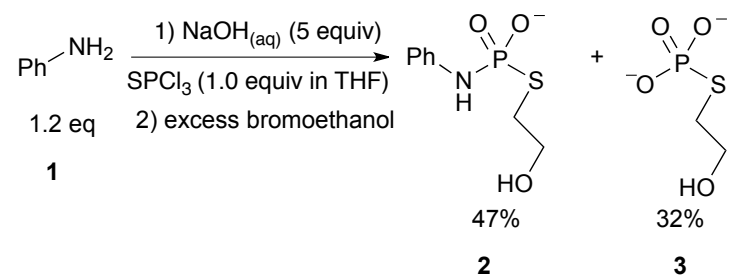

15 Scheme $2 N$-Thiophosphorylation and $S$-alkylation of aniline.

\section{Phenylalanine}

Post-translational phosphorylation of proteins represents a major signalling pathway, and access to phosphoproteins and their analogues supports the delineation of these key processes. In 20 addition, phosphorylation of the carboxyl group of amino acids serves to activate the carbonyl group for substitution during coded protein biosynthesis. Furthermore, phosphonamide systems have been widely exploited as transition state mimics for the attack of water upon the cabonyl of amides (Figure 1). To date, a 25 limited number of examples of aqueous amino acid phosphorylations have been reported. Metatriphosphate ion possesses an activated anhydride structure that has been shown to be an effective $N$-phosphorylating agent for amino acids. In addition to $\mathrm{N}$-phosphorylation, in the context of an amino acid, 30 the carboxylate group acts as an internal nucleophile, displacing pyrophosphate ion and forming a cyclic mixed anhydridephosphoramidate species. Cyclic phosphate esters show enhanced electrophilicity over their acyclic counterparts, and in this guise, the cyclic mixed anhydride-phosphoramidates show 35 electrophilicity towards water at the phosphoryl centre and amines at the carbonyl. Histidine side chains of proteins have also been successfully modified with thiophosphorylating agents ( $\mathrm{PSCl}_{3}$ and thiophosphoramidate ion) in order to prepare more hydrolytically stable analogues of phosphohistidyl proteins that 40 are intermediates in a variety of signalling enzymes. ${ }^{16-18}$

With these ideas in mind, we hoped to apply $\mathrm{PSCl}_{3}$ towards the primary amino function of phenylalanine and alkylate the resulting thiophosphoramidate ion to produce carboxamide hydrolysis transition state analogues (Figure 1).

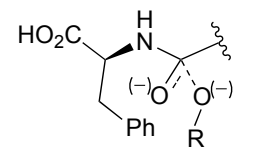

TS for amide hydrolysis

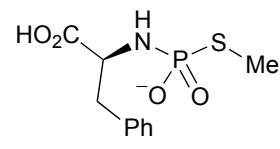

thiophosphoramidate TSA
Figure 1 Structural resemblance of amide hydrolysis and amino acid- $N$-thiophosphoramidates.

Using 1.0 eq phenylalanine, 7.0 eq $\mathrm{NaOH}$ and 1.4 eq $\mathrm{PSCl}_{3}$, $85 \% \quad N$-thiophosphoryaltion was observed by ${ }^{31} \mathrm{P} \quad \mathrm{NMR}$ 50 spectroscopy (Scheme 3) after removal of inorganic thiophosphate through selective precipitation. The remainder of the P-containing impurites included $N$-phosphoramidate $(\sim 10 \%)$ and several unidentified species.

$S$-Alkylation was attempted in $\mathrm{D}_{2} \mathrm{O}$ using methyl iodide, ss however, only $24 \%$ conversion to the $N, S$ dialkylthiophosphoramidate 4 was observed. The remainder of the P-containing materials included significant quantites of the $\mathrm{N}$ phosphoramidate and phosphate ion.

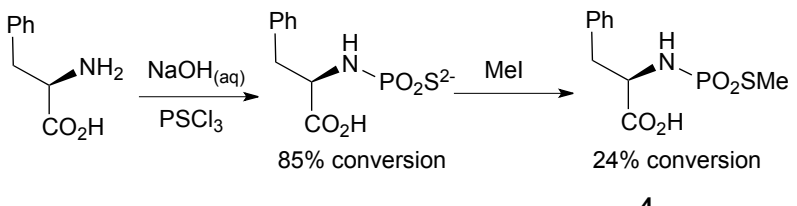

Scheme $3 N$-Thiophosphorylation-S-alkylation of phenylalanine.

Mass spectrometric analysis of the $N$-thiophosphorylation mixture also revealed significant quantities of $N$-phosphoramidate 5 plus Phe-Phe dimer 6, however, the analysis was performed 65 under acidic conditions, which were likely to encourage desulfurisation.

Taken together, these pieces of evidence strongly support the idea of intramolecular assistance of the carboxyl group in the decomposition of the $S$-alkylated thiophosphoramidate (or the 70 protonated thiophosphoramidate ion), where the cyclic mixed anhydride intermediate 7 likely facilitates the formation of several of the decomposition products (Scheme 4). 


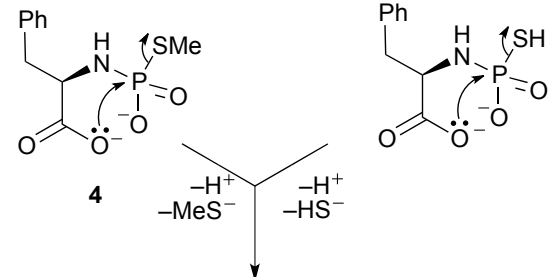

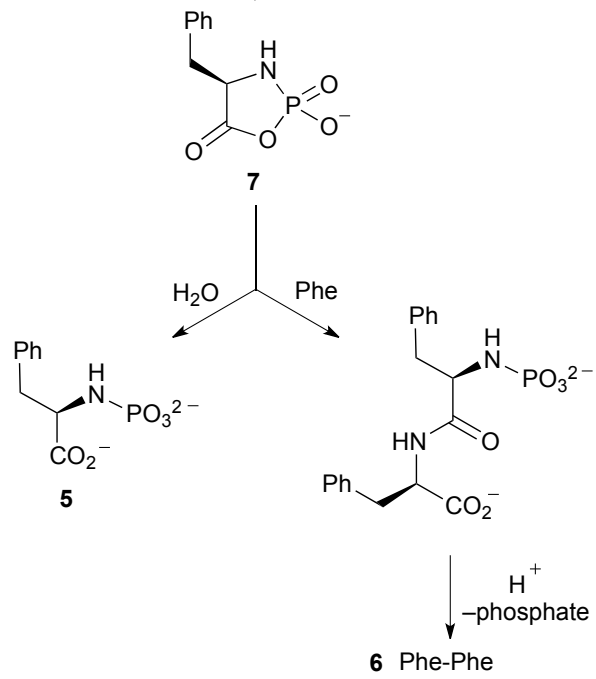

Scheme 4 Possible intramolecular reactions of phenylalaninebased thiophosphoramidate systems.

\section{Glucosamine}

${ }_{5}$ Phospho-sugar systems play many biological roles and we hoped that we would be able to gain access to phospho-sugar mimics using our approach. Glucosamine was chosen as a readily avialable model substrate for our preliminary study. Others have investigated aqueous sugar phosphorylation procedures using 10 metatriphosphate ion and its imino analogue, however, yields were low. The preparation of sugar phosphoramidates that go on to afford a phosphosugars has also been investigated, and good yields $(79 \%)$ were reported.

A preliminary thiophosphorylation experiment using a 1:1 15 ratio of glucosamine 8 to $\mathrm{PSCl}_{3}$ gave a rewarding $\sim 90 \%$ conversion (estimated from a signal $\sim 45.5 \mathrm{ppm}$ in the ${ }^{31} \mathrm{P} \mathrm{NMR}$ spectrum) to the $N$-thiophosphoramidate 9. Over a time course of $\sim 1 \mathrm{~h}$, however, this signal dimished, with new signals appearing at similar chemical shifts. At present, we are not able to assign

20 these, however, they are consistent with thiophosphoryl groups that have not been $S$-alkylated. Indeed, they may represent phosphorothioates that have arisen through intramolecular isomerisation. Despite this process, we proceeded with $S$ alkylation using MeI. This led to a majority of the P-containing ${ }_{25}$ product mixture being converted to $S$-methylated inorganic phosphate ion 10. The large proportion of N-P bond scission suggests that once alkylated, intramolecular reaction facilitates this cleavage, unlike simple $N, S$-dialkyl thiophosphoramidates, which appear to be stable under the reaction conditions. A 30 tentative decomposition mechanism for the glucosamine system is presented in Scheme 5. The key difference between this system and the Phe system is the potential for intramolecular acid catalysis via the 1-OH group, which, as an acetal, could act as an acid at the relatively high $\mathrm{pHs}$ used for thiophosphorylation (and
35 alkylation). Smaller signals $\sim 10-12 \mathrm{ppm}$ are consistent with $N$ phosphoramidates that result from desulfurisation processes, where the two signals may signify the $\alpha$ - and $\beta$-anomers. On the basis of these preliminary results, we did not explore this system further, however, delivery of such a reactive phosphoryl donor to 40 an enzyme active site may offer a useful tool for enzyme labelling or capture, and may also offer uses as a synthetic phosphorylation tool.

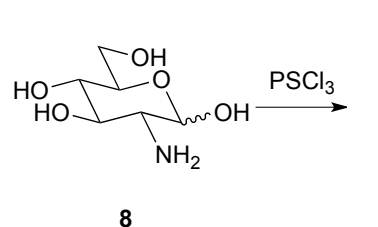<smiles>O=P([O-])([S-])NC(O)C(O)C(O)C(O)CO</smiles>

9

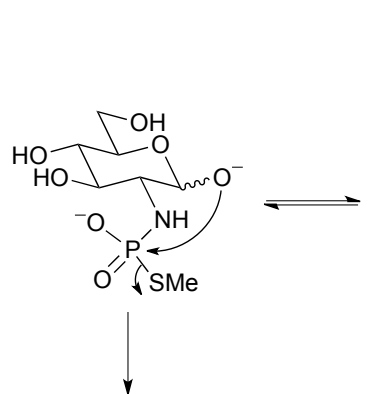

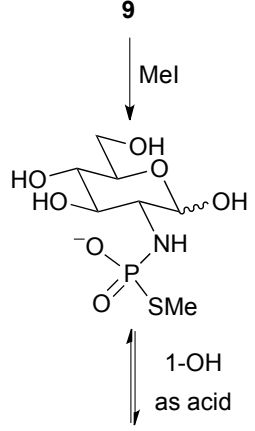<smiles>O=P([O-])(O)NC1C2OC(CO)C(CO)(CO)C1O2</smiles>

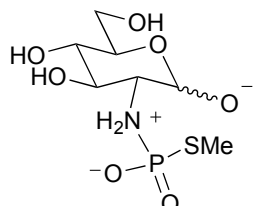<smiles>C1CCOC1</smiles>
$\mathrm{H}_{2} \mathrm{O} \downarrow$<smiles>O=P([O-])([O-])NC(C(O)O)C(O)C(O)CO</smiles><smiles>COP(=O)(OC)O[C-]O[C@](N)(O)C(N)C1C(O)C(O)C(O)C1O</smiles>

10

Scheme $5 \mathrm{~N}$-Thiophosphorylation-alkylation of glucosamine 45

5'-Amino-5'-deoxyguanosine

and

5'-Amino-5'deoxyadenosine

Nucleoside phosphates are ubiquitous in biological systems, and a range of $\mathrm{N}$-containing and $\mathrm{S}$-containing phosphate mimics have 50 been reported, with uses in mechanistic studies and antisense/siRNA applications. We have already reported the alkylation of $N$-thiophosphoramidate using a nucleoside-5'iodide, and reasonable conversions were observed. Alkylation with the nucleoside-5'-iodide, however, proved to be very slow in ${ }_{55}$ comparison to other alkylating agents (see below). With this in mind, we sought to explore the $N$-thiophosphorylation of 5 'amino-5'-deoxynucleoside substrates and their subsequent alkylation.

We prepared adenosine and guanosine aminonucleosides 11a${ }_{60} \mathbf{b}$ using established procedures. The adenosine system 11b was isolated as its hydrochloride salt, thus an additional equivalent of 
$\mathrm{NaOH}$ was employed during thiophosphorylation. Alkylations were then performed using MeI, and, ion both cases, the $S$ alkylated aminonucleoside- $N$-thiophosphormaidates 12a-b were formed at conversions levels $\sim 70 \%$. Given that unprotected 5 nucleosides were employed, this level is impressive, however, chromatographic purification was necessary (see ESI) in order to confirm the identity of all the reaction products.

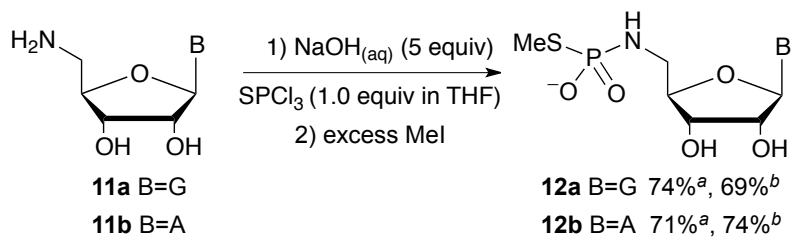

Scheme 6 N-Thiophosphorylation-alkylation on 5'aminonucleosides.

The desired thiophosphoramidate products eluted $\sim 35-40 \mathrm{~min}$ which correponded to $\sim 100-140 \mathrm{mM}$ TEAB. The areas under the absorbance-elution time profiles were also used to estimate conversion to the desired products, and the values were in ${ }_{15}$ agreement with the observations from ${ }^{1} \mathrm{H}$ and ${ }^{31} \mathrm{P}$ NMR spectroscopies.

\section{$S$-Alkylation}

In order to achieve effective alkylation, we explored the effects of $\mathrm{pH}$, stoichiometry, reaction time and temperature on model 20 substrates. In addition, we explored the kinetics of alkylation of a range of thiophosphoramidate ions and alkylating agents. The stability of the $S$-alkylated thiophosphoramidates was also explored. These results are summarised in the following subsections.

\section{${ }_{25}$ Stability of $\boldsymbol{N}$-thiophosphoamidate ions}

In line with $N$-phosphoramidates, we expected $N$ thiophosphoramidates to display greater stability at higher pHs. In order to explore this idea, we conducted ${ }^{31} \mathrm{P}$ NMR kinetic studies using ethanolamine- $N$-thiophosphoramidate $\mathbf{1 3}$ as ${ }_{30}$ substrate. The use of ${ }^{31} \mathrm{P}$ NMR spectroscopy allowed us to monitor the decomposition of the ethanolamine- $N$ thiophosphoramidate and to gain insight into the identities of the resulting hydrolysis products through the use of chemical shift and signal multiplicity data. The substrate was dissolved in $4 \mathrm{M}$

35 or $0.5 \mathrm{M}$ buffer, the water was removed by lyophilisation and the residue was redissolved in $\mathrm{D}_{2} \mathrm{O}$. This provided solutions where $\sim 90 \%$ of the labile protons had been exchanged for deuterium to enable a deuterium lock signal to be used. The use of $4 \mathrm{M}$ buffer solutions, ensured the $\mathrm{pH}$ changes observed during kinetic 40 experiments were small, however, the presence of large concentrations of sodium ions caused problems with the measurement of $\mathrm{pH}$. This manifested itself in the form of deviation from the expected gradient of -1 in the $\log k_{\mathrm{obs}}-\mathrm{pH}$ plot for $\mathrm{pH}>8$. On this basis, some of the experminets at higher $\mathrm{pHs}$ 45 were repeated using $0.5 \mathrm{M}$ buffers. Under these conditions, greater changes in $\mathrm{pH}(0.2-0.5)$ were observed during the courses of the kinetic experiments, however, a gradient of -1 was observed for the log $k_{\mathrm{obs}} \mathrm{pH}$ data at higher $\mathrm{pHs}$ (Figure 2). Caution should also be taken in terms of the interpretation of
${ }_{50}$ measured $\mathrm{pH}$ values where the extent of deuteriation within the buffer is not clearly defined.

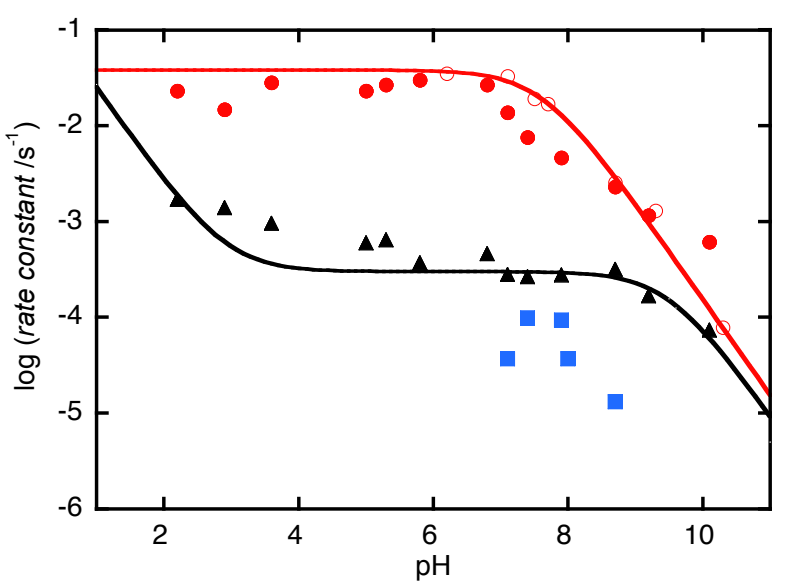

Figure $2{ }^{31} \mathrm{P}$ NMR spectroscopy study of the hydrolysis of ethanolamine- $N$-thiophosphoramidate ion as a function of $\mathrm{pH}$. 55 Red circles represent rate constants for the disappearance of ethanolamine- $N$-thiophosphoramidate ion (closed, stronger buffers; open, weaker buffers); black triangles represent the appearance of phosphate ion (a similar trace for the

disappearance of thiophosphate ion was also observed; not shown); and blue squares represent the appearance of ethanolamine- $N$-phosphoramidate ion.

Closer analysis of the ${ }^{31} \mathrm{P}$ NMR spectra shows that in addition of $\mathrm{P}-\mathrm{N}$ scission to give amine and inorganic thiophosphate ion, desulfurisation of both the $N$-thiophosphoramidate substrate $\mathbf{1 3}$ ${ }_{65}$ and thiophosphate ion occurs (Scheme 7) to give $N$ phosphoramidate $\mathbf{1 4}$ and phosphate ion, respectively. ${ }^{9}, 10,19$ Desulfurisation of the $\mathrm{N}$-thiophosphoramidate ion, however, was only detectable for $7<\mathrm{pH}<9$, whereas desulfurisation of thiophosphate ion was seen across the profile. Rate constants for 70 the processes discussed above have been estimated, however, the compromises made in terms of the use of buffers to facilitate the use of ${ }^{31} \mathrm{P}$ NMR spectroscopy, mean that these rate constants should only be considered on an order-of-magnitude basis. On the $\mathrm{pH}$ plateaux, disappearance of thiophosphoramidate shows a rate 75 constant of $\sim 4 \times 10^{-2} \mathrm{~s}^{-1}$; appearance of phosphate, $5 \times 10^{-4} \mathrm{~s}^{-1}$; and appearance of phosphoramidate, $\sim 6 \times 10^{-5} \mathrm{~s}^{-1}$. Taken together, however, these data give clear evidence that $N$ thiophosphoramidate species display similar pH-reactivity properties to their oxy-analogues, and the use of higher $\mathrm{pH}$ would 80 appear to be the most relaible pathway towards $S$-alkylation. In addition, these data align well with the findings of Ora et al. and their studies on closely related systems.

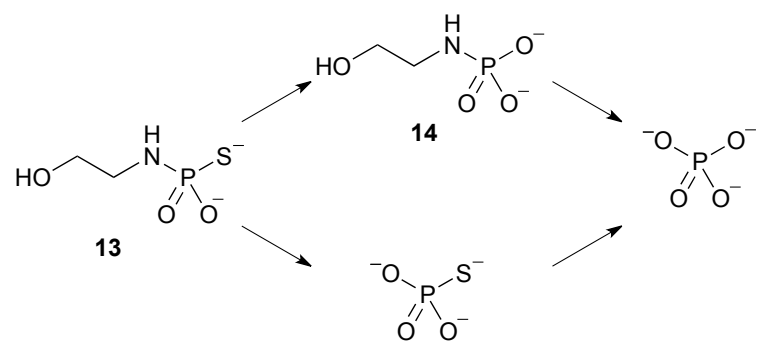


Scheme 7 Hydrolytic breakdown products of ethanolamine- $N$ thiophosphoramidate.

\section{Stability of $N, S$-dialkylthiophosphoramidates}

To gain an appreciation of the stability of $N, S$-dialkyl ${ }_{5}$ thiophosphoramidates, we performed ${ }^{31} \mathrm{P}$ NMR spectroscopybased studies on $N$-benzylamino- $S$ - $n$-propylthiophosphoramidate at $\mathrm{pH} \sim 7.5$ and $\sim 5.2$. The $\mathrm{pH}$ of 7.5 was chosen to be close to physiological $\mathrm{pH}$, whereas the $\mathrm{pH} 5.2$ provides a situation where $\mathrm{N}$-protonation is more likely, and reactivity is expected to be 10 higher. In addition, the lower $\mathrm{pH}$ aligns with the conditions used for amastigote testing, which will be discussed below. The samples were incubated at $37{ }^{\circ} \mathrm{C}$ and ${ }^{31} \mathrm{P}$ NMR spectra were recorded periodically. No changes the forms of the spectra were observed over the course of $16 \mathrm{~h}$. On the basis of these results, 15 where we would expect to be able to detect $5 \%$ degradation reliably using the NMR method, we predict half-lives $>200 \mathrm{~h}$ in both cases. Whilst this picture suffices for the development of our synthetic procedures, further detailed kinetic studies will be required.

\section{${ }_{20}$ Bromoacetamides as alkylating agents}

In order to expand the range of potential alkylating agents available for elaboration of $N$-thiophosphoramidate ions, we explored the use of a heterobifunctional cross-linking agents. We envisioned $\mathbf{1 5}$ being able to react selectively with 25 thiophosphoramidate ions to produce activate acylating agents $\mathbf{1 6}$ that could be further reacted with readily accesible amines to produce mixed phosphoryl-acyl systems $\mathbf{1 7}$ that may serve as pyrophosphate mimics (Scheme 8). Our earlier experiences with a thiophosphate anion-based system (uridine-5'30 monophosphorothioate, UMPS), suggested that this strategy could offer a convenient aqueous route to these species. ${ }^{20}$

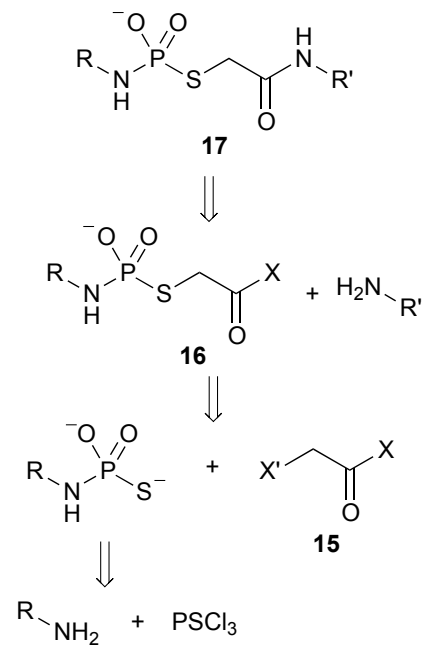

Scheme 8 (A) Disconnection strategy for thiophosphoramidatebromoacetate ester ligation of two amines. (B) Structural resemblance of thiophosphoryl-acetamide system to pyrophosphate.

Based on our earlier work with thiophosphates, we performed exploratory studies on the use of $p$-nitrophenyl-, $m$-nitrophenyl and phenyl-bromoacetate esters 15a-c respectively. Our aim was 40 to balance hydrolysis of the activated ester against the desired aminolysis process by tuning the reactivity of the phenolate leaving group. We used benzylamine as a model substrate for thiophosphorylation given that we had observed this process to proceed quantitatively. The second amine, $\mathrm{RNH}_{2}$, was either the 45 model system, allylamine, or the more challenging 5'-amino-5'deoxyguanosine (Scheme 9).

$$
\text { R= }
$$

Scheme 9 Amine-amine ligation via thiophosphorylationbromoacetate ester cross-linking.

50 After each reaction, excess amine $\mathrm{RNH}_{2}$ was removed by increasing $\mathrm{pH}$ followed by extraction with organic solvent. The $\mathrm{pH}$ was then reduced to facilitate protonation of the phenolate leaving groups by extraction into organic solvent. In all cases, the majority of material was converted to the desired ${ }_{55}$ thiophosphoramidate-acetamide products $\mathbf{1 6}$ and $\mathbf{1 7}$.

In order to confirm the identity of the guanosine-derived product 16, ion exchange chromatography was carried out. As seen for the $N$-thiophosphorylated aminonucleoside systems (see above), the desired thiophosphoramidate product 16 eluted $\sim 35$ ${ }_{60} 40 \mathrm{~min}$ which corresponded $\sim 90 \mathrm{mM}$ TEAB (see ESI). The conversion level estimated by measuring the area under the absorbance curve in the elution profile correlated well with observations from ${ }^{1} \mathrm{H}$ and ${ }^{31} \mathrm{P}$ NMR spectroscopies.

These preliminary studies illustrate that the thiophosphorylation${ }_{65}$ bromoacetate route could offer a simple route towards nucleoside-based systems. Further optimisation of conditions, reaction times and the choice of phenolate leaving group should facilitate improvements.

\section{Nucleophilicity of thiophosphoryl systems}

70 During our alkylation studies, we observed that some alkylations appeared more sluggish than others, thus we sought to explore these observations through kinetic studies. In addition to being sensitive to the nature of the electrophile, we expected the kinetics of alkylation to vary as a function of the nature of the $\mathrm{N}$ 75 alkyl portion of the thiophosphramidate. We studied the progress of a series of alkylations reaction using ${ }^{31} \mathrm{P}$ NMR spectroscopy using ethanolamine- $N$-thiophosphoramidate 13, benzylamine- $N$ thiophosphoramidate $\mathbf{1 8}$, and, as a comparison, inorganic thiophosphate ion as nucleophiles. The added electrophiles were 80 bromoethanol and 5'-deoxy-5'-iodoguanosine 1 (Scheme 10). 


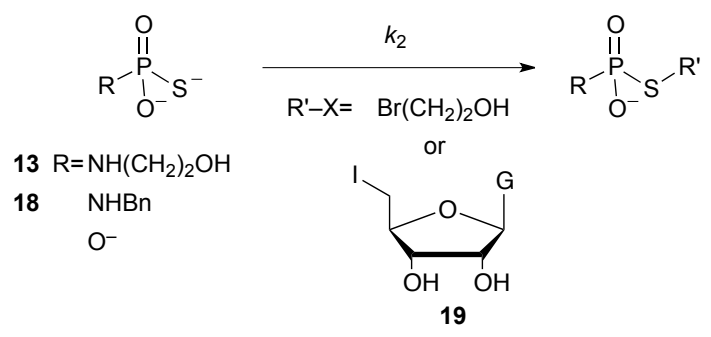

Scheme 10 Thiophosphoryl systems and alkylating agents used in $S$-alkylation kinetic study.

Alkylations were performed in the presence of a significant 5 excess of alkylating agent to facilitate first order kinetic analyses. Using the reactive bromoethanol system, alkylations proceeded rapidly, thus we were unable to derive kinetic data. With the less reactive nucleoside system, however, bimolecular rate constants, $k_{2}$, of $4 \times 10^{-5}, 2.5 \times 10^{-4}$ and $3.3 \times 10^{-4} \mathrm{M}^{-1} \mathrm{~s}^{-1}$ were obtained for 10 ethanolamine- $N$-thiophosphoramidate 13 , benzylamine- $N$ thiophosphoramidate $\mathbf{1 8}$ and inorganic thiophosphate ion, respectively. These data confirm that the nature of the substituent on the thiophosphoryl group can have a significant effect on alkylation kinetics.

15 The nucleophilicity of thiolate ions can be measured quantitatively, and we would expect these values to be similar in nature to thiocarboxylate systems studies by Mayr and coworkers. ${ }^{21} \mathrm{We}$ are currently exploring these values.

\section{Preparation of $N, S$-dialkylthiophosphoramidate ${ }_{20}$ libraries using lipophilic alkylamines}

To prove the general applicability of the method, we preparaed a small generic library of $N, S$-dialkyl thiophosphoramidates 2033a-c in a simple, rapid manner where the only form of purification was extraction of excess alkylating agent followed by 25 removal of the aqueous solvent. All amines were hydrophobic in nature, and some of the reaction mixtures were heterogeneous.

Table 2. Preparation of a library of N,S-dialkyl thiophosphoramidates and control compound.

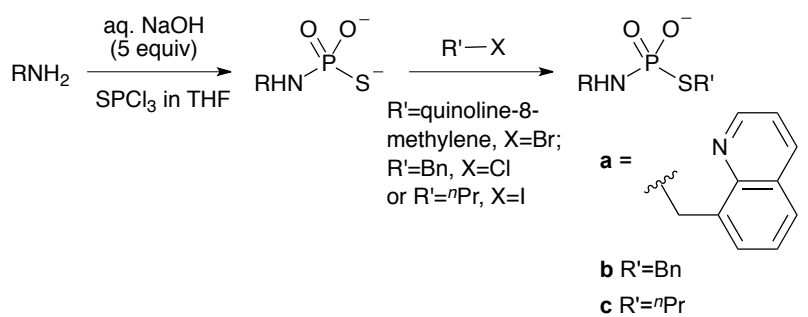

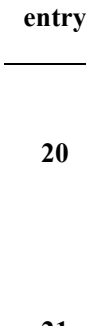<smiles>[NH3+]P(=O)([O-])NCc1ccc(-c2ccccc2)cc1</smiles>

22<smiles>O=P([O-])([Sn])NCc1cccc2ccccc12</smiles>

23<smiles>O=P([O-])(S)NCc1ccccc1Sc1ccccc1CO</smiles>

a $90^{a}, 90^{b}$ b $92^{a}, 94^{b}$ c $93^{a}, 94^{b}$

24<smiles>[NH3+]P(=O)(O)NCc1ccc2ccc3cccc4ccc1c2c34</smiles>

25<smiles>C[N+]([O-])([O-])P(=O)([O-])Cc1c2ccccc2cc2ccccc12</smiles>

a $61^{a}, 80^{b}$ b $99^{a}, 100^{b}$ c $97^{a}, 94^{b}$

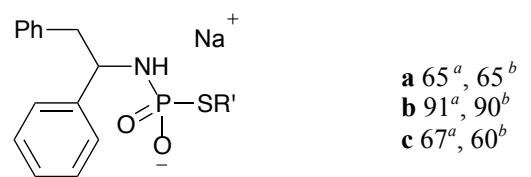

27<smiles>O=P([O-])([Hg])NCc1ccccc1</smiles>

a $91^{a}, 95^{b}$<smiles>C=CCNP(=O)([O-])[Hg]</smiles>

a $93^{a}, 96^{b}$ $\%$ b $97^{a}, 97^{b}, 92^{c}$

\section{$90^{b}$} b b n level,

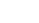
$98^{a}, 100^{b}, 100^{c}$ $7^{b}$

.


30<smiles>O=P([O-])([Hg])NCCc1ccccn1</smiles>
a $87^{a}, 75^{b}$ c $95^{a}, 82^{b}$

31<smiles>O=P([O-])([Hg])NC1CCCc2ccccc21</smiles>

a $75^{a}, 78^{b}$ c $79^{a}, 87^{b}$

32<smiles>O=P([O-])([Hg])NCCCN1CCOCC1</smiles>

$81^{a}, 67^{b}$ c $91^{a}, 90^{b}$

33<smiles>O=P([O-])([Hg])NCc1ccc(F)cc1</smiles>

$90^{a}, 92^{b}, 84^{c}$ c $96^{a}, 96^{b}, 100^{c}$

34<smiles>O=P([O-])([O-])SCc1cccc2cccnc12</smiles>

$95^{a}, 93^{b}$

${ }^{a}$ Determined by ${ }^{31} \mathrm{P}$ NMR spectroscopy. ${ }^{b}$ Determined by ${ }^{1} \mathrm{H}$ NMR spectroscopy. ${ }^{c}$ Determined by ${ }^{19}$ F NMR spectroscopy.

Alkylating agents were represented by benzyl chloride, $n$-propyl iodide and a quinoline system. The simple alkyl systems served 5 to illustrate the usage of a reactive benzyl system and a simple alkyl system. The quinolines, on the other hand were designed by analogy with quinoline-based sulfamidates that have been successfully applied as anti-parasite agents. The syntheses of the sulfonamides were, however, by way of organic solvent-based 10 procedures where laborious purification procedures were required. We hoped that the similar geometric properties of the thiophosphoramidate group may offer an alternative to the sulfonamide where product mixture could be used directly from aqueous synthetic procedures without isolation.

\section{${ }_{15}$ Testing Antileishmanial Activities}

Quinoline-substituted sulfonamides have been reported as potential anti-leishmanial agents (Figure 4). ${ }^{22,23}$<smiles>[R]OS(=O)(=O)Nc1cccc2cccnc12</smiles>

Figure 4 Quinoline-based sulfonamides used in antileishmanial testing studies.

Owing to the close structural homology of the thiophosphoramidate and sulfonamide groups, we prepared quinoline-based thiophosphoramidate derivatives 20-33a. In addition, phosphorothiolate-quinoline system $\mathbf{3 4}$ was prepared as

25 a control that represents the common hydrolysis product expected from P-N scission. We tested these systems for activity againist both mammalian stage amastigote and insect stage promastigote forms of the Trypanosomatid Leishmania mexicana using established protocols. ${ }^{24}$ Unfortunately, there were no clear signs 30 of activity of these agents. In the case of amastigotes, we found that the quinoline systems were quite sensitive to the acidic nature of the specialist growth media, and showed significant decomposition over a timescale of hours. This contrasts with our findings for other systems, and we attribute this difference to the 35 possibility of intramolecular general acid catalysis in the quinolines (Scheme 11).

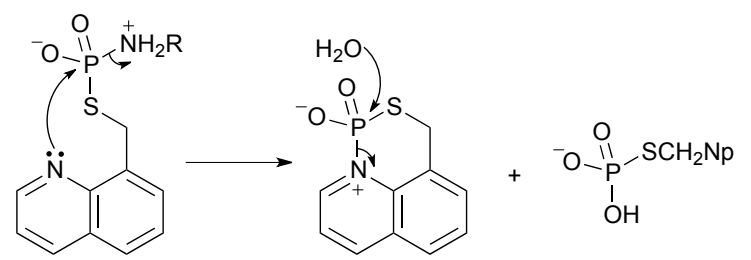

Scheme 11 Potential intramolecular mechanism accounting for the instability of quinoline-based thiophosphoramidates.

40 Promastigote tesing also failed to demonstrate antileishmanial activity, thus we must conclude that $N$-alkyl-S-(methylene(8quinolyl)) thiophosphoramidates are not effective against Leishmania mexicana, despite their structural resemblance to successful sulfonamide compounds.

\section{${ }_{45}$ Conclusions}

Aqueous aminothiophosphorylation offers clean conversion to thiophosphoramidate anions when used in conjunction with nucleophilic, simple alkylamines, however, aryl systems have proven less successful. Unprotected amino acid, sugar and so nucleoside systems showed varying degrees of effectiveness, with the aminonucleoside systems showing significant promise and scope for improved performance. In these cases, thiophosphorylations proceeded, in most cases, smoothly, however, on $S$-alkylation, decomposition was seen. In all cases, 55 mechanisms involving intramolecular assistance can be postulated, and it is these that we believe lead to the decomposition in these systems.

The straightforward assembly of simple liphophilic systems using $\mathrm{PSCl}_{3}$ allowed us to rapidly assemble a library of ${ }_{60}$ compunds, and, although the quinoline systems presented specific stability issues, the approach proved effective in facilitating swift access to aqueous solutions of library molecules that were amenable to biological testing without needing extensive purification.

\section{${ }_{65}$ Experimental}

Attempted thiophosphorylation-alkylation of aniline (towards 2, 3)

Aniline (1.2 eq, $251 \mu \mathrm{L}, 2.76 \mathrm{mmol})$ was mixed with aqueous sodium hydroxide (5 eq of a $1 \mathrm{M}$ aqueous solution, $11.5 \mathrm{ml}, 11.5$ $70 \mathrm{mmol})$ and water $(1.48 \mathrm{ml})$ in a $50 \mathrm{~mL}$ round bottomed flask with indentations aimed towards inducing turbulent mixing. The mixture was cooled on an ice-water bath, thiophosphoryl chloride 
(1.0 eq, $232 \mu \mathrm{L}, 2.3 \mathrm{mmol})$ in THF $(7 \mathrm{~mL})$ was added dropwise over the course of $10 \mathrm{~min}$. and the mixture was stirred for an additional $15 \mathrm{~min}$. Bromoethanol ( $2 \mathrm{eq}, 326 \mu \mathrm{L}, 4.6 \mathrm{mmol}$ ) was added and the mixture was stirred for $22 \mathrm{~h}$ while maintaining ${ }_{5} \mathrm{pH} \sim 9$ through periodic additions of $1 \mathrm{ml}$ aliquots of $1 \mathrm{M} \mathrm{NaOH}$ solution. The mixture was then extracted with diethyl ether $(3 \times 10 \mathrm{~mL})$ to remove excess aniline, $\mathrm{PSCl}_{3}, \mathrm{THF}$ and bromoethanol, and the aqueous layer was concentrated by lyophilisation before being subjected to analysis. The conversion 10 to $N$-thiophosphoramidate was estimated by ${ }^{31} \mathrm{P} \quad \mathrm{NMR}$ spectroscopy before addition of bromoethanol (see ESI). After addition of the alkylating agent, conversion was estimated using ${ }^{31} \mathrm{P}$ NMR spectroscopy (47\%) and ${ }^{1} \mathrm{H}$ NMR spectroscopy (41\%). The other impurities present were aniline $19 \%$ and alkylated 15 inorganic thiophosphosphate $31 \%$ by both ${ }^{31} \mathrm{P}$ NMR and ${ }^{1} \mathrm{H}$ NMR spectroscopy. $\delta_{\mathrm{H}}\left(400 \mathrm{MHz} ; \mathrm{D}_{2} \mathrm{O}\right) 7.26(2 \mathrm{H}, \mathrm{t}, J 7.9, m-\mathrm{Ar}-\mathrm{H})$, 7.09 (2 H, d, J 8.0, o-Ar-H), 6.99-6.90 (1 H, m, p-ArH), 3.56 (2 $\left.\left.\mathrm{H}, \mathrm{t}, J 6.4, \mathrm{CH}_{2} \mathrm{OH}\right), 2.78-2.65(2 \mathrm{H}, \mathrm{m}, \mathrm{SCH})_{2}\right) \delta_{\mathrm{P}}(162 \mathrm{MHz}$; $\left.\mathrm{D}_{2} \mathrm{O}\right) 18.7\left(\mathrm{t},{ }^{3} J_{\mathrm{H}-\mathrm{P}} 13.4, \mathrm{~N} P \mathrm{~S}\right) ; \delta_{\mathrm{C}}\left(101 \mathrm{MHz} ; \mathrm{D}_{2} \mathrm{O}\right) 141.7,129.6$, $20121.3,118.2\left(\mathrm{~d},{ }^{3} J_{\mathrm{C}-\mathrm{P}} 6.7, C \mathrm{HCNH}\right), 61.6\left(\mathrm{~d},{ }^{3} J_{\mathrm{C}-\mathrm{P}} 4.7, \mathrm{CH}_{2} \mathrm{OH}\right)$, $32.5\left(\mathrm{SCH}_{2}\right) ; \mathrm{m} / z\left(\mathrm{ES}^{-}\right) 232.0203\left(\mathrm{M}-\mathrm{H} . \mathrm{C}_{8} \mathrm{H}_{11} \mathrm{NO}_{3} \mathrm{PS}\right.$ requires 232.0203).

\section{Attempted thiophosphorylation-alkylation of phenylalanine (towards 4)}

${ }_{25} \mathrm{D} / \mathrm{L}$-phenylalanine (1 eq, $2.3 \mathrm{mmol}, 380 \mathrm{mg}$ ) was dissolved in aqueous sodium hydroxide ( 7 eq of a $5 \mathrm{M}$ aqueous solution, 3.22 $\mathrm{ml}, 16.1 \mathrm{mmol}$ ) in a $50 \mathrm{~mL}$ round bottomed flask with indents in an ice bath. Thiophosphoryl chloride (1.4 eq, $327 \mu \mathrm{L}, 3.22 \mathrm{mmol}$ ) in THF $(4 \mathrm{~mL})$ was added dropwise to the mixture over the 30 course of $10 \mathrm{~min}$. After $1 \mathrm{~h}$ of stirring, inorganic thiophosphate ion arising from hydrolysis of the excess $\mathrm{PSCl}_{3}$ was removed by applying methanol precipitation. ${ }^{25}$ The residual supernatant solution was concentrated in vacuo before being freeze-dried to remove water and being subjected to NMR analysis. The crude 35 phenylalanine thiophosphoramidate $(0.5 \mathrm{mmol}, 130.5 \mathrm{mg})$ was dissolved in $\mathrm{D}_{2} \mathrm{O}(0.5 \mathrm{ml})$ and $\mathrm{MeI}(0.5 \mathrm{mmol}, 31 \mu \mathrm{L})$ was added directly to the NMR. The sample was subjected to NMR analysis after $20 \mathrm{~h}$. Analysis after thiophosphorylation; $\delta_{\mathrm{H}}(400 \mathrm{MHz}$; $\left.\mathrm{D}_{2} \mathrm{O}\right)$ 7.34-7.02 (5 H, m, Ar-H), 3.76 (1 H, ddd, $J$ 12.4, 7.9, 4.5, $\left.{ }_{40} \mathrm{CH}\right), 3.06(1 \mathrm{H}, \mathrm{dd}, J 13.1$ and $4.5, \mathrm{CH} H), 2.79(1 \mathrm{H}, \mathrm{dd}, J 13.1$ and 7.9, $\mathrm{C} H \mathrm{H}) ; \delta_{\mathrm{P}}\left(162 \mathrm{MHz} ; \mathrm{D}_{2} \mathrm{O}\right) 42.3\left(\mathrm{~d},{ }^{3} J_{\mathrm{H}-\mathrm{P}} 12.5, \mathrm{~N} P \mathrm{~S}\right) ; \mathrm{m} / z$ $\left(\mathrm{ES}^{+}\right) 262.03\left(\mathrm{M}+\mathrm{H}^{+}\right) ; \mathrm{m} / z\left(\mathrm{ES}^{-}\right) 244.0383$ (phosphoramidate i.e. loss of $\mathrm{S},(\mathrm{M}-\mathrm{H}) . \mathrm{C}_{9} \mathrm{H}_{11} \mathrm{NO}_{5} \mathrm{P}$ requires 244.0380). Analysis after addition of MeI; $\delta_{\mathrm{H}}\left(400 \mathrm{MHz} ; \mathrm{D}_{2} \mathrm{O}\right) 7.53-7.05(6 \mathrm{H}, \mathrm{m}, \mathrm{Ar}-\mathrm{H})$, 45 3.90-3.68 (1 H, m, CH), 3.21-3.07 (2 H, m, CH$), 1.67(3 \mathrm{H}, \mathrm{d}, J$ $\left.13.3, \mathrm{SCH}_{3}\right) ; \delta_{\mathrm{P}}\left(162 \mathrm{MHz} ; \mathrm{D}_{2} \mathrm{O}\right) 25.1\left(\mathrm{~d},{ }^{3} J_{\mathrm{H}-\mathrm{P}} 12.8, \mathrm{~N} P \mathrm{~S}\right)$.

Attempted thiophosphorylation-alkylation of glucosamine (towards 9,10)

Glucosamine hydrochloride (1.0 eq, $496 \mathrm{mg}, 2.3 \mathrm{mmol}$ ) was ${ }_{50}$ dissoved in aqueous sodium hydroxide (6 eq of a $1 \mathrm{M}$ aqueous solution, $13.8 \mathrm{ml}, 13.8 \mathrm{mmol}$ ) in a $50 \mathrm{~mL}$ round bottomed flask with indents in an ice bath. Thiophosphoryl chloride (1.0 eq, 232 $\mu \mathrm{L}, 2.3 \mathrm{mmol})$ in THF $(7 \mathrm{~mL})$ was added dropwise to the mixture over the course of $10 \mathrm{~min}$. After $1 \mathrm{~h}$ of stirring, the conversion to 55 thiophosphoramidate was estimated by ${ }^{31} \mathrm{P}$ NMR spectroscopy MeI $(2.0 \mathrm{Eq}, 4.6,286 \mu \mathrm{L})$ was added and the mixture was stirred for a further $1 \mathrm{~h}$ and subjected to ${ }^{31} \mathrm{P}$ NMR spectroscopy analysis to assess $S$-alkylation. Analysis after thiophosphorylation; $\delta_{\mathrm{P}}(162$ $\mathrm{MHz} ; \mathrm{D}_{2} \mathrm{O}$ ) 45.6 (NPS). After addition of MeI, the majority of 60 material appeared to be converted to $S$-methylthiophosphate 10; $\delta_{\mathrm{P}}\left(162 \mathrm{MHz} ; \mathrm{D}_{2} \mathrm{O}\right) 19.3$ (d, ${ }^{3} J_{\mathrm{H}-\mathrm{P}} 11.3$, OPSMe$)$.

Thiophosphorylation of 5'-amino-5'deoxyguanosine or 5'amino-5'deoxyadenosine and alkylation with $\mathrm{MeI}$ or $\mathrm{BnCl}$

5'-Amino-5'-deoxyguanosine 25 (1 Eq, $0.23 \mathrm{mmol}$ ) or 5'${ }_{65}$ Amino-5'-deoxyadenosine dihydrochloride ${ }^{27}$ (1 Eq, $0.23 \mathrm{mmol}$ ) was dissolved in a mixture of aqueous sodium hydroxide (5 eq of a $1 \mathrm{M}$ solution, $1.15 \mathrm{mmol}$ for $\mathrm{G}$; $7 \mathrm{eq}, 1.61 \mathrm{mmol}$ for $\mathrm{A}$ ) and water $(148 \mu \mathrm{L}$ for $\mathrm{G}, 0 \mu \mathrm{L}$ for $\mathrm{A})$ in a $50 \mathrm{~mL}$ round bottomed flask with indents in an ice bath. Thiophosphoryl chloride 70 ( $1 \mathrm{Eq}, 23.2 \mu \mathrm{L}, 0.23 \mathrm{mmol})$ in THF $(0.7 \mathrm{~mL})$ was added dropwise to the aqueous solution over the course of $10 \mathrm{~min}$. and the mixture was then stirred for a further $1 \mathrm{~h}$. Methyl iodide ( $2 \mathrm{Eq}$, $28.6 \mu \mathrm{L}, 0.46 \mathrm{mmol}$ ) and additional aqueous sodium hydroxide solution $(1 \mathrm{Eq})$ were added to the flask and stirring was continued 75 for $1 \mathrm{~h}$. The excess of alkylating agent was removed by ether extraction $(3 \times 10 \mathrm{~mL})$. The residual aqueous solution was then lyophilised and the residues were analysed (see crude ${ }^{1} \mathrm{H}$ and ${ }^{31} \mathrm{P}$ NMR spectra in ESI). The crude samples were dissolved in a 50 $\mathrm{mM}$ TEAB buffer, $\mathrm{pH} 7.5(5 \mathrm{~mL})$ and purified on DEAE 80 Sepharose ${ }^{\circ} \mathrm{FF}$ column $(50 \mathrm{~mL}, 10 \times 3 \mathrm{~mm}, 3 \mathrm{~mL} / \mathrm{min})$, running TEAB buffer gradient $50-200 \mathrm{mM}$. Fractions were pooled and lyophilised before confirmation of their identities by ${ }^{1} \mathrm{H}$ and ${ }^{31} \mathrm{P}$ NMR spectroscopies. The triethylammonium salts of the compounds were dissolved in water $(5 \mathrm{~mL})$ and passed through a ${ }_{85} \mathrm{Na}^{-D_{0}}{ }^{\star} 50 \mathrm{~W} \times 2,200-400(50 \mathrm{~mL}, 30 \times 2 \mathrm{~mm}, 3 \mathrm{~mL} / \mathrm{min})$ column, with water as the mobile phase. The fractions containing products, detected via UV trace $(254 \mathrm{~nm})$, were collected, lyophilised and spectroscopic analyses were performed on the residues.

$9011 \mathrm{a}$

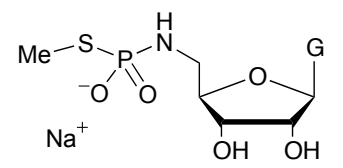

$\delta_{\mathrm{H}}\left(700 \mathrm{MHz} ; \mathrm{D}_{2} \mathrm{O}\right) 7.71(1 \mathrm{H}, \mathrm{s}, 8-H), 5.66\left(1 \mathrm{H}, \mathrm{d}, J 7.8,1^{\prime}-\mathrm{C} H\right)$, 4.98-4.94 (1 H, m, 2'-CHOH), 4.31-4.28 (1 H, m, 3'-CHOH), 4.22-4.19 (1 H, m, 4'-CH), 3.06-2.99 (2 H, m, 5'-CH $\left.{ }_{2}\right), 1.97$ (3 ${ }_{95} \mathrm{H}, \mathrm{d}, J$ 13.0, $\left.\mathrm{CH}_{3} \mathrm{~S}\right) ; \delta_{\mathrm{P}}\left[{ }^{1} \mathrm{H}\right]\left(283 \mathrm{MHz} ; \mathrm{D}_{2} \mathrm{O}\right)$ 26.4-26.1 (m, $\mathrm{NHPS}) ; \delta_{\mathrm{C}}\left(176 \mathrm{MHz} ; \mathrm{D}_{2} \mathrm{O}\right)$ not assigned owing to low spectrum intensity; $m / z\left(\mathrm{ES}^{-}\right) 391.0594\left(\mathrm{M}-\mathrm{H} . \mathrm{C}_{11} \mathrm{H}_{16} \mathrm{~N}_{6} \mathrm{O}_{6} \mathrm{PS}\right.$ requires 391.0595).

$11 \mathbf{b}$

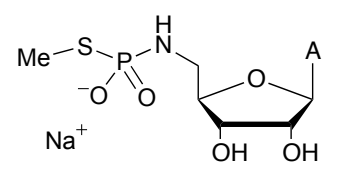

$\delta_{\mathrm{H}}\left(700 \mathrm{MHz} ; \mathrm{D}_{2} \mathrm{O}\right) 8.20(1 \mathrm{H}, \mathrm{s}, 2-H), 8.08(1 \mathrm{H}, \mathrm{s}, 8-H), 5.88(1$ $\mathrm{H}, \mathrm{d}, J$ 6.6, 1'-CH), 4.76 (1 H, t, $J$ 5.4, 2'-CHOH), 4.33-4.29 (1 $\mathrm{H}, \mathrm{m}, 3$ ' $-\mathrm{CHOH}), 4.17-4.13$ (1 H, m, 4'-CH), 3.13-3.00 (2 H, m, 5'- $\left.\mathrm{NH}_{2} \mathrm{CH}_{2}\right), 1.95\left(3 \mathrm{H}, \mathrm{d}, J 13.1, \mathrm{CH}_{3} \mathrm{~S}\right) ; \delta_{\mathrm{P}}\left[{ }^{1} \mathrm{H}\right](283 \mathrm{MHz}$; $\left.{ }_{105} \mathrm{D}_{2} \mathrm{O}\right) 26.1-25.8(\mathrm{~m}, \mathrm{NH} P \mathrm{~S}) ; \delta_{\mathrm{C}}\left(176 \mathrm{MHz} ; \mathrm{D}_{2} \mathrm{O}\right)$ 155.6, 152.8, 
$148.9,140.8,140.6,119.0,87.7(1 '-C H), 85.1$ (d, ${ }^{3} J_{\mathrm{C}-\mathrm{P}} 8.7,4$ '$\mathrm{CH}), 73.1$ (2'- $\mathrm{CHOH}), 71.1$ (3'- $\mathrm{CHOH}), 43.3\left(5^{\prime}-\mathrm{NH}_{2} \mathrm{CH}_{2}\right), 11.6$ (d, $\left.{ }^{2} J_{\mathrm{C}-\mathrm{P}} 3.4, \mathrm{CH}_{3} \mathrm{~S}\right) ; \mathrm{m} / \mathrm{z}\left(\mathrm{ES}^{-}\right) 375.0643\left(\mathrm{M}-\mathrm{H} . \mathrm{C}_{11} \mathrm{H}_{16} \mathrm{~N}_{6} \mathrm{O}_{5} \mathrm{PS}\right.$ requires 375.0646).

${ }_{5}$ Kinetic studies on the decomposition of ethanolamine- $N$ thiophosphoroamidate 13

Buffers were prepared using CAPS (pH 10.5 and 10.17), CHES (pH 9.81, 9.44 and 9.06), EPPS ( $\mathrm{pH} 8.44$ and 8.00), HEPES (pH 7.50 and 7.10), MES (pH 6.60, 6.00 and 5.88) and acetate $(\mathrm{pH}$ 104.80 and 4.66) systems where the pHs were adjusted by the addition of hydrochloric acid or hydroxide solutions (see ESI). Crude, lyophilised ethanolamine thiophosphoroamidate $\mathbf{1 3}$ $(30 \mathrm{mg})$ was dissolved in a buffer solution $(0.5 \mathrm{M}, 4 \mathrm{~mL}$ or 0.5 $\mathrm{mL}$, see ESI) and the mixture was lyophilised. The lyophilised 15 solid was then dissolved in $\mathrm{D}_{2} \mathrm{O}(0.5 \mathrm{~mL})$, a $\mathrm{pH}$ meter reading was taken and the mixture was transferred to a NMR tube. Owing to the fact that a rigorous deuterium exchange was not performed, the measured $\mathrm{pD}$ value could not be converted directly to a $\mathrm{pD}$ value, however, for the purposes of this preliminary study, the 20 uncertainty in these values $(\sim 0.1 \mathrm{pD}$ units $)$ was deemed acceptable. The NMR tube containing the buffered substrate was then heated to $50{ }^{\circ} \mathrm{C}$ in the NMR machine magnet, and spectra were acquired every 30 (CAPS, CHES, EPPS, HEPES), 15 (MES), 10 (acetate buffer) or 8 (citric buffer) minutes.

${ }_{25}$ The intensities of the peaks corresponding to the thiophosphoroamidate, normalised with the highest intensity peak in the spectra, set to have the value 1, were plotted as a pseudo first order function of time and least squares fittings were performed against an exponential decay curve $\mathrm{I}_{t}=\mathrm{I}_{0} \mathrm{e}^{-k t}$.

\section{Bromoacetamide cross-linker}

Use of benzylamine- $N$-thiophosphoramidate 18 with phenylbromoacetates $15 \mathrm{a}-\mathrm{b}$ and allyl amine or 5'-amino-5'deoxyguanosine

Benzylamine (1 Eq, $25 \mu \mathrm{L}, 0.23 \mathrm{mmol}$ ) was thiophosphorylated 35 using our established procedure. Allylamine $(2 \mathrm{Eq}, 32 \mu \mathrm{L}$, $0.46 \mathrm{mmol}) \quad$ or $\quad 5$ '-amino-5'deoxyguanosine (1 Eq, $65 \mathrm{mg}, 0.23 \mathrm{mmol}$ ) was added to aqueous/THF solution of the thiophosphorylated benzylamine and mixed for several minutes, before the phenylbromoacetate ester $(1 \mathrm{Eq}, 0.23 \mathrm{mmol})$

40 was added. After 15 minutes of vigorous stirring, the $\mathrm{pH}$ of the mixture was adjusted using $50 \mathrm{mM}$ hydrochloric acid to the approximately the $\mathrm{p} K_{\mathrm{a}}$ of the phenol leaving group. The solution was extracted with ethyl acetate $(3 \times 10 \mathrm{~mL})$, the $\mathrm{pH}$ was adjusted to $\mathrm{pH} 9$ and the extraction was performed using chloroform

${ }_{45}(3 \times 10 \mathrm{~mL})$ in an atempt to remove excess amine. The aqueous sample was lyophilized and the dry solid was analysed and purified (nucleoside). 17

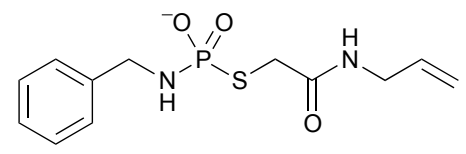

${ }_{50} \delta_{\mathrm{H}}\left(400 \mathrm{MHz} ; \mathrm{D}_{2} \mathrm{O}\right) 7.45-7.22\left(5 \mathrm{H}, \mathrm{m}, \mathrm{C}_{6} H_{5}\right), 5.85-5.74(1 \mathrm{H}, \mathrm{m}$, $\left.\mathrm{CH}_{2}=\mathrm{CH}\right), 5.20-5.10\left(2 \mathrm{H}, \mathrm{m}, \mathrm{CH}_{2}=\mathrm{CH}\right), 4.00(2 \mathrm{H}, \mathrm{d}, J$ 10.9, $\left.\mathrm{CH}_{2} \mathrm{NH}\right), 3.72\left(2 \mathrm{H}, \mathrm{dt}, J 5.1\right.$ and 1.6, $\left.\mathrm{NHCH}_{2}\right), 3.33(2 \mathrm{H}, \mathrm{d}, J$ 12.9, $\left.\mathrm{SCH} \mathrm{H}_{2}\right) ; \delta_{\mathrm{P}}\left[{ }^{1} \mathrm{H}\right]\left(162 \mathrm{MHz} ; \mathrm{D}_{2} \mathrm{O}\right) \quad 22.0-21.6$ (m, NHPS);
$\delta_{\mathrm{C}}\left(101 \mathrm{MHz} ; \mathrm{D}_{2} \mathrm{O}\right) 172.4\left(\mathrm{~d},{ }^{3} J_{\mathrm{C}-\mathrm{P}} 3.6, C=\mathrm{O}\right), 140.6\left(\mathrm{~d},{ }^{3} J_{\mathrm{C}-\mathrm{P}} 7.6\right.$, $\left.{ }_{55} \mathrm{CCH}_{2} \mathrm{NH}\right), \quad 133.6 \quad\left(\mathrm{CH}=\mathrm{CH}_{2}\right), \quad 128.9, \quad 128.8, \quad 127.4, \quad 116.4$ $\left(\mathrm{CH}_{2}=\mathrm{CH}\right), 45.6\left(\mathrm{PhCH}_{2} \mathrm{NH}\right), 42.2\left(\mathrm{CH}_{2} \mathrm{CH}=\mathrm{CH}_{2}\right), 33.7\left(\mathrm{SCH}_{2}\right)$; $\mathrm{m} / z\left(\mathrm{ES}^{-}\right) 299.0627\left(\mathrm{M}-\mathrm{H} . \mathrm{C}_{12} \mathrm{H}_{16} \mathrm{~N}_{2} \mathrm{O}_{3}\right.$ PS requires 299.0624). 16

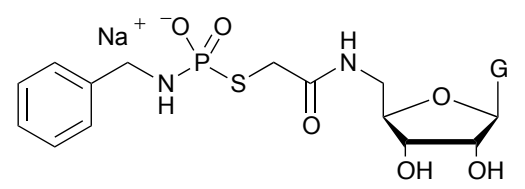

${ }_{60}$ The crude sample $(50 \mathrm{mg})$ was dissolved in a $50 \mathrm{mM}$ TEAB buffer, $\mathrm{pH} 7.5(5 \mathrm{~mL})$ and purified on DEAE Sepharose $\mathrm{FF}$ column $(50 \mathrm{~mL}, 10 \times 3 \mathrm{~mm}, 3 \mathrm{~mL} / \mathrm{min})$, running TEAB buffer gradient 50-200 mM. Fractions were pooled and lyophilised, and the main peak in the UV trace was found to contain the desired ${ }_{65}$ product $\left(87 \%\right.$ by ${ }^{31} \mathrm{P}$ NMR spectroscopy, $78 \%$ by ${ }^{1} \mathrm{H}$ NMR spectroscopy). The triethylammonium salt of the compound was dissolved in water $(5 \mathrm{~mL})$ and passed through a Na-Dowex $50 \mathrm{~W} \times 2,200-400(50 \mathrm{~mL}, 30 \times 2 \mathrm{~mm}, 3 \mathrm{~mL} / \mathrm{min})$ column, with water as the mobile phase. The fractions containing product, 70 detected via UV trace $(254 \mathrm{~nm})$, were collected and lyophilised. The purity after cation exchange chromatography was estimated to be $80 \%$ by ${ }^{31} \mathrm{P}$ NMR spectroscopy and $68 \%$ by ${ }^{1} \mathrm{H}$ NMR spectroscopy). $\delta_{\mathrm{H}}\left(700 \mathrm{MHz} ; \mathrm{D}_{2} \mathrm{O}\right) 7.74(1 \mathrm{H}, \mathrm{s}, 8-H), 7.10-6.99$ (5 H, m, Ar-H), 5.58 (1 H, d, J 4.5, 1'-CH), 4.47 (1 H, app t, $J$ 75 5.0, 2'-CHOH), 4.17 (1 H, app t, $J$ 5.3, 3'- $-\mathrm{CHOH}), 4.11-4.07$ (1 $\mathrm{H}, \mathrm{m}, 4$ '-CH), 3.71-3.60 (2 H, m, $\left.\mathrm{CH}_{2} \mathrm{NH}\right), 3.49$ (1 H, dd, J 14.3 and 7.4, 5' $\left.-\mathrm{CH}_{2}\right), 3.43$ ( $1 \mathrm{H}$, dd, $J 14.6$ and 3.4, 5' $\left.-\mathrm{CH}_{2}\right), 3.29-$ $3.17\left(2 \mathrm{H}, \mathrm{m}, \mathrm{SCH} \mathrm{H}_{2}\right) ; \delta_{\mathrm{P}}\left[{ }^{1} \mathrm{H}\right]\left(162 \mathrm{MHz} ; \mathrm{D}_{2} \mathrm{O}\right) 22.7-22.5(\mathrm{~m}$, $\mathrm{NHPS}) ; \delta_{\mathrm{C}}\left(101 \mathrm{MHz} ; \mathrm{D}_{2} \mathrm{O}\right) 172.9\left(\mathrm{~d},{ }^{3} J_{\mathrm{C}-\mathrm{P}} 2.6, C=\mathrm{O}\right), 158.7$, $80153.7,151.1,140.2,137.4,128.8,128.5,128.2,127.5,127.3$, $126.9,126.7,116.5,87.7\left(1^{\prime}-\mathrm{CH}\right), 82.0\left(4^{\prime}-\mathrm{CH}\right), 73.4 \quad\left(2^{\prime}-\right.$ $\mathrm{CHOH}), 70.9$ (3'- $\mathrm{CHOH}), 45.0\left(\mathrm{CH}_{2} \mathrm{NH}\right), 41.4\left(5^{\prime}-\mathrm{CH}_{2}\right), 33.4$ (d, $\left.{ }^{2} J_{\mathrm{C}-\mathrm{P}} 12.4, \mathrm{SCH}_{2}\right) ; m / z\left(\mathrm{ES}^{-}\right) 524.1127\left(\mathrm{M}-\mathrm{H} . \mathrm{C}_{19} \mathrm{H}_{23} \mathrm{~N}_{7} \mathrm{O}_{7} \mathrm{PS}\right.$ requires 524.1123).

${ }_{85}$ Kinetic study of the alkylation of thiophosphate ion using 5'deoxy-5'-iodoguanosine 19.

A stock solution of $100 \mathrm{mM} \mathrm{NaOH}$ with $10 \% \mathrm{D}_{2} \mathrm{O}$ was made with $\mathrm{NaOH}(0.5 \mathrm{ml}, 1 \mathrm{M}), \mathrm{H}_{2} \mathrm{O}(4 \mathrm{ml})$ and $\mathrm{D}_{2} \mathrm{O}(0.5 \mathrm{ml}) .5$ '-iodo 5'-deoxyguanosine $(19 \mathrm{mg}, 0.05 \mathrm{mmol})$ and tribasic sodium 90 thiophosphate $(0.09 \mathrm{~g}, 0.5 \mathrm{mmol})$ were dissolved in the stock $\mathrm{NaOH}$ solution $(0.5 \mathrm{ml})$. The solution was transferred into a NMR tube and reaction progress at $50{ }^{\circ} \mathrm{C}$ was monitored in the NMR spectrometer by ${ }^{31} \mathrm{P}$ NMR spectroscopy $(202 \mathrm{MHz}, 128$ repetitions). Two runs were performed with time points being ${ }_{95}$ taken either every $1 \mathrm{~h}$ or every $10 \mathrm{~min}$.

Kinetic studies of the alkylations of benzylamine- $N$ thiophosphoroamidate 18 and ethanolamine-Nthiophosphoroamidate 13 ion with bromoethanol and 5'deoxy-5'-iodoguanosine 19.

100 5'-iodo-5'-deoxyguanosine 19 (19 mg, $0.05 \mathrm{mmol})$ or 2bromoethanol $(3.5 \mu \mathrm{L}, 0.05 \mathrm{mmol})$ was measured directly into an NMR tube. Crude benzylamine- $N$-thiophosphoroamidate (101.5 $\mathrm{mg}$ ) or ethanolamine- $N$-thiophosphoroamidate $(78.5 \mathrm{mg})$ was dissolved in $\mathrm{D}_{2} \mathrm{O}(0.5 \mathrm{~mL})$ and added to the alkylating agent. The 105 mixture was then subjected to ${ }^{31} \mathrm{P}$ NMR spectroscopic analyses at 
$50{ }^{\circ} \mathrm{C}$ over a period of $12 \mathrm{~h}$, with spectra being collected every 30 minutes. All the signals appearing in the spectra were integrated. The normalised peak area for the signal at $25 \mathrm{ppm}$ (quintet in the coupled spectra, $J=10.7 \mathrm{~Hz}$ ), corresponding to the alkylated product, was then plotted against time and these data were used for kinetic fittings.

$\mathrm{N}$-thiophosphorylation of simple hydrophobic amine library and $S$-alkylation of the resulting $N$-thiophosphoramidate anions 20-33a-c.

10 Details of quantities are summarized in tabular format in the Electronic Supplementary Information.

An amine (ESI table 3, $\mathrm{RNH}_{2}$ ) was mixed with sodium hydroxide solution (5 Eq of a $1 \mathrm{M}$ aqueous solution: 20-33a: $0.9 \mathrm{~mL}, 0.9 \mathrm{mmol} ; \mathbf{2 0 - 3 3 b , c : ~} 2.425 \mathrm{~mL}, 2.425 \mathrm{mmol}$ ) and water 15 (20-33a: $0.116 \mathrm{~mL} ; \mathbf{2 0 - 3 3 b , c : ~} 0.312 \mathrm{~mL}$ ) in a round-bottomed flask with indentations that aim to ensure turbulent mixing. Thiophosphoryl chloride (1 Eq, 20-33a: $0.18 \mathrm{mmol}, 0.018 \mathrm{~mL}$; 20-33b,c: $0.049 \mathrm{~mL}, 0.485 \mathrm{mmol})$ dissolved in THF (20-33a: $0.548 \mathrm{~mL}$; 20-33b,c: $1.476 \mathrm{~mL}$ ) was added dropwise to the 20 aqueous mixture over the course of $10 \mathrm{~min}$. After $1 \mathrm{~h}$ of vigorous mixing to allow $N$-thiophosphorylation to take place, an alkylating agent was added (ESI table 3) along with additional sodium hydroxide solution (ESI table 3 ) and vigorous mixing was continued fo either 1 h (20-33a) or overnight (20-33b,c). Then, 25 ether extraction was performed (20-33a: $3 \times 5 \mathrm{~mL} ; \mathbf{2 0 - 3 3 b}, \mathbf{c}$ : $3 \times 20 \mathrm{~mL}$ ) and the aqueous layer was lyophilized. In the examples where a white precipitate appeared during the extraction, the sample was centrifuged and the precipitate was dried overnight in a vacuum desiccator before being analysed. ${ }_{30}$ The crude material was then subjected to ${ }^{1} \mathrm{H}$ and ${ }^{31} \mathrm{P}$ NMR analyses to assess conversion levels, and ${ }^{13} \mathrm{C}$ NMR analyses were used to confirm the identity of the major product.

\section{Summary of Spectroscopic Data.}

20a<smiles></smiles>

$\delta_{\mathrm{H}}\left(700 \mathrm{MHz} ; \mathrm{CD}_{3} \mathrm{OD}\right)$ 8.78-8.75 $(1 \mathrm{H}, \mathrm{m}, \mathrm{Ar}-\mathrm{H}), 8.20-8.17(1 \mathrm{H}$, $\mathrm{m}, \mathrm{Ar}-\mathrm{H}), 7.82(1 \mathrm{H}, \mathrm{d}, J$ 7.0, Ar-H), 7.73-7.67 (2 H, m, Ar-H), $7.50\left(1 \mathrm{H}\right.$, br s, $\left.\mathrm{CF}_{3} \mathrm{CCHC}\right), 7.48-7.32(4 \mathrm{H}, \mathrm{m}, \mathrm{Ar}-\mathrm{H}) 4.56(2 \mathrm{H}$, d, $\left.J 11.2, \mathrm{CH}_{2} \mathrm{NH}\right), 3.80\left(2 \mathrm{H}, \mathrm{d}, J 8.6, \mathrm{SCH}_{2}\right) ; \delta_{\mathrm{P}}\left[{ }^{1} \mathrm{H}\right](283 \mathrm{MHz}$; $\left.{ }_{40} \mathrm{CD}_{3} \mathrm{OD}\right) 23.7-23.4(\mathrm{~m}, \mathrm{NH} P \mathrm{~S}) ; \delta_{\mathrm{F}}\left(376 \mathrm{MHz} ; \mathrm{CD}_{3} \mathrm{OD}\right)-63.8(\mathrm{~s}$, $\left.\mathrm{C} F_{3}\right) ; \quad \delta_{\mathrm{C}}\left(176 \mathrm{MHz} ; \mathrm{CD}_{3} \mathrm{OD}\right) 149.2,145.7,142.2$ (d, ${ }^{3} J_{\mathrm{C}-\mathrm{P}} 10.8$, $\mathrm{CCH}_{2} \mathrm{NH}$ ), 138.0 (m, ${ }^{3} J_{\mathrm{C}-\mathrm{P}}$ not resolved, $\mathrm{SCH}_{2} \mathrm{C}$ ), 136.5, 130.9, $129.7,128.7,128.4,126.9,126.2-126.0\left(\mathrm{~m},{ }^{2} J_{\mathrm{C}-\mathrm{F}}\right.$ not resolved, $\mathrm{Ar}), 124.9\left({ }^{1} J_{\mathrm{C}-\mathrm{F}} 272, \mathrm{CF}_{3}\right), 123.9-123.7$ ( $\mathrm{m},{ }^{3} J_{\mathrm{C}-\mathrm{F}}$ not resolved), 45122.8 (q, $\left.{ }^{3} J_{\mathrm{C}-\mathrm{F}} 3.0, \mathrm{Ar}\right), 121.0,45.6\left(\mathrm{CH}_{2} \mathrm{NH}\right), 30.0\left(\mathrm{SCH}_{2}\right)$, the other peaks have not been resolved; $\mathrm{m} / z\left(\mathrm{ES}^{-}\right) 411.0547(\mathrm{M}-\mathrm{H}$. $\mathrm{C}_{18} \mathrm{H}_{15} \mathrm{~N}_{2} \mathrm{O}_{2} \mathrm{~F}_{3}$ PS requires 411.0549). 20b

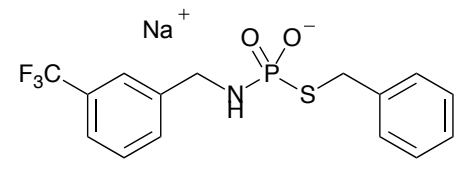

so $\delta_{\mathrm{H}}\left(700 \mathrm{MHz} ; \mathrm{CD}_{3} \mathrm{OD}\right) 7.61\left(1 \mathrm{H}, \mathrm{s}, \operatorname{Ar}\left(\mathrm{CF}_{3}\right)\right), 7.52(1 \mathrm{H}, \mathrm{d}, J$ 7.6, $\left.\operatorname{Ar}\left(\mathrm{CF}_{3}\right)\right), 7.46\left(1 \mathrm{H}, \mathrm{d}, J\right.$ 7.6, $\left.\operatorname{Ar}\left(\mathrm{CF}_{3}\right)\right), 7.43(1 \mathrm{H}, \mathrm{t}, J$ 7.6, $\left.\operatorname{Ar}\left(\mathrm{CF}_{3}\right)\right), 7.32(2 \mathrm{H}, \mathrm{d}, J$ 7.6, $\mathrm{Ar}-\mathrm{H}), 7.23(2 \mathrm{H}$, app t, $J$ 7.5, Ar$\mathrm{H}), 7.15\left(1 \mathrm{H}, \mathrm{t}, J\right.$ 7.3, Ar-H), $3.91\left(2 \mathrm{H}, \mathrm{d}, J\right.$ 9.3, $\left.\mathrm{SCH} H_{2}\right), 3.86(2$ $\mathrm{H}, \mathrm{d}, J 10.1, \mathrm{CH}_{2} \mathrm{NH}$ ); $\delta_{\mathrm{P}}\left[{ }^{1} \mathrm{H}\right]\left(283 \mathrm{MHz} ; \mathrm{CD}_{3} \mathrm{OD}\right.$ ) 22.3 (app qn, $J$ $\left.{ }_{55} 9.3, \mathrm{NH} P \mathrm{~S}\right) ; \delta_{\mathrm{F}}\left(376 \mathrm{MHz} ; \mathrm{CD}_{3} \mathrm{OD}\right)-63.9\left(\mathrm{~s}, \mathrm{C} F_{3}\right) ; \delta_{\mathrm{C}}(176 \mathrm{MHz}$; $\mathrm{CD}_{3} \mathrm{OD}$ ) 142.8-142.7 (m, Ar), 140.0-139.9 (m, Ar), 131.0, 130.0 (q, $\left.{ }^{2} J_{C-F} 31\right), 128.45,128.40,127.9,126.3,124.4\left(\mathrm{q},{ }^{1} J_{C-F} 272\right.$, $\mathrm{CF}_{3}$ ), 123.8-123.7 (m, $\left.{ }^{3} J_{C-F}, \mathrm{Ar}\right), 122.9$ (q, $\left.{ }^{3} J_{C-F} 3.8, \mathrm{Ar}\right), 45.4$ $\left(\mathrm{CH}_{2} \mathrm{NH}\right), \quad 34.6 \quad\left(\mathrm{SCH}_{2}\right) ; \quad m / z \quad\left(\mathrm{ES}^{-}\right) \quad 360.04420 \quad(\mathrm{M}-\mathrm{H}$. ${ }_{60} \mathrm{C}_{15} \mathrm{H}_{14} \mathrm{NO}_{2} \mathrm{~F}_{3} \mathrm{PS}$ requires 360.04405$)$. 20c<smiles>CCCSP(=O)([O-])NCc1cccc(C(F)(F)F)c1</smiles>

$\delta_{\mathrm{H}}\left(700 \mathrm{MHz} ; \mathrm{CD}_{3} \mathrm{OD}\right) 7.83(1 \mathrm{H}, \mathrm{br} \mathrm{s}, \mathrm{Ar}-\mathrm{H}), 7.65(1 \mathrm{H}, \mathrm{d}, J 6.8$, $\mathrm{Ar}-\mathrm{H}), 7.51-7.46(2 \mathrm{H}, \mathrm{m}, \mathrm{Ar}-\mathrm{H}), 4.12\left(2 \mathrm{H}, \mathrm{d}, J 10.1, \mathrm{SCH}_{2}\right)$, ${ }_{65} 2.61\left(2 \mathrm{H}, \mathrm{dt}, J 10.2\right.$ and 7.4, $\left.\mathrm{SCH}_{2}\right), 1.60(2 \mathrm{H}$, app sx, $J$ 7.4, $\left.\mathrm{CH}_{2} \mathrm{CH}_{3}\right), 0.99\left(3 \mathrm{H}, \mathrm{t}, J\right.$ 7.4, $\left.\mathrm{CH}_{2} \mathrm{CH}_{3}\right) ; \delta_{\mathrm{P}}\left[{ }^{1} \mathrm{H}\right](283 \mathrm{MHz}$; $\left.\mathrm{CD}_{3} \mathrm{OD}\right) 23.7$ (app qn, $J 10.2, \mathrm{NHPS}$ ); $\delta_{\mathrm{F}}\left(376 \mathrm{MHz} ; \mathrm{CD}_{3} \mathrm{OD}\right)-$ $63.9\left(\mathrm{~s}, \quad \mathrm{C} F_{3}\right) ; \quad \delta_{\mathrm{C}}\left(176 \mathrm{MHz} ; \mathrm{CD}_{3} \mathrm{OD}\right) 142.9$ (d, ${ }^{3} J_{\mathrm{C}-\mathrm{P}} 7.4$, $\left.\mathrm{CCH}_{2} \mathrm{NH}\right), 131.0(4-\mathrm{CH}), 130.0\left(\mathrm{q},{ }^{2} J_{C-F} 31.5, C_{C F}\right), 128.4(5-$ $\left.{ }_{70} C \mathrm{H}\right), 124.3\left(\mathrm{q}, J_{C-F} 271, C \mathrm{~F}_{3}\right), 123.9\left(\mathrm{q},{ }^{3} J_{C-F} 3.2,2-C \mathrm{H}\right), 122.8(\mathrm{q}$, $\left.{ }^{3} J_{C-F} 3.6,6-C H\right), 45.4\left(\mathrm{CH}_{2} \mathrm{NH}\right), 32.3\left(\mathrm{SCH}_{2}\right), 24.2\left(\mathrm{~d},{ }^{3} J_{\mathrm{C}-\mathrm{P}} 6.8\right.$, $\left.\mathrm{CH}_{2} \mathrm{CH}_{3}\right), \quad 12.7 \quad\left(\mathrm{CH}_{2} \mathrm{CH}_{3}\right) ; \quad m / z \quad\left(\mathrm{ES}^{-}\right) \quad 312.04392 \quad(\mathrm{M}-\mathrm{H}$. $\mathrm{C}_{11} \mathrm{H}_{14} \mathrm{NO}_{2} \mathrm{~F}_{3}$ PS requires 312.04405).

21a<smiles>O=P([O-])(NCc1ccc(-c2ccccc2)cc1)SCc1cccc2cccnc12</smiles>

$\delta_{\mathrm{H}}\left(500 \mathrm{MHz} ; \mathrm{CD}_{3} \mathrm{OD}\right) 8.80(1 \mathrm{H}, \mathrm{dd}, J 4.2$ and $1.8, \mathrm{Ar}-\mathrm{H}), 8.21$ $(1 \mathrm{H}, \mathrm{dd}, J 8.2$ and 1.8, Ar-H), 7.81 (1 H, d, J 7.0, Ar-H), 7.74 (1 $\mathrm{H}$, dd, $J 8.2$ and 1.3, Ar-H), 7.59-7.24 (8 H, m, Ar-H), 7.22-7.20 ( $2 \mathrm{H}, \mathrm{m}, \mathrm{Ar}-\mathrm{H}), 4.56\left(2 \mathrm{H}, \mathrm{d}, J 11.2, \mathrm{CH}_{2} \mathrm{NH}\right), 3.80$ (2 H, d, J 8.2, $\left.{ }_{80} \mathrm{SCH}_{2}\right) ; \delta_{\mathrm{P}}\left[{ }^{1} \mathrm{H}\right]\left(283 \mathrm{MHz} ; \mathrm{CD}_{3} \mathrm{OD}\right)$ 23.8-23.6 (m, NHPS); $\delta_{\mathrm{C}}(125$ $\left.\mathrm{MHz} ; \mathrm{CD}_{3} \mathrm{OD}\right) \quad 149.2,145.8,140.8,140.1 \quad\left(\mathrm{~d},{ }^{3} J_{C-p} \quad 10.5\right.$, $\mathrm{CCH}_{2} \mathrm{NH}$ ), 139.3, 138.0 (d, $\left.{ }^{3} J_{\mathrm{C}-\mathrm{P}} 4.4, \mathrm{SCH}_{2} \mathrm{C}\right), 136.6,129.7$, 128.6, 128., 127.8, 126.8, 126.4, 126.3, 126.2, 126.0, 120.8, 45.5 $\left(\mathrm{CH}_{2} \mathrm{NH}\right), \quad 30.1 \quad\left(\mathrm{SCH}_{2}\right) ; \quad m / z \quad\left(\mathrm{ES}^{-}\right) \quad 419.0993 \quad(\mathrm{M}-\mathrm{H}$. ${ }_{85} \mathrm{C}_{23} \mathrm{H}_{20} \mathrm{~N}_{2} \mathrm{O}_{2}$ PS requires 419.0988 ). 21b<smiles>O=P([O-])(NCc1ccc(-c2ccccc2)cc1)SCc1ccccc1</smiles>

$\delta_{\mathrm{H}}\left(700 \mathrm{MHz} ; \mathrm{CD}_{3} \mathrm{OD}\right) 7.57(2 \mathrm{H}, \mathrm{d}, J$ 7.8, Ar-H), $7.50(2 \mathrm{H}, \mathrm{d}, J$ 7.8, Ar-H), 7.40 (2 H, t, J 7.6, Ar-H), 7.35 (2 H, d, J 7.8, Ar-H), 90 7.32-7.27 (3 H, m, Ar-H), 7.21 (2 H, d, J 7.5, Ar-H), 7.14 (1 H, t, $J$ 7.5, Ar-H), $3.91\left(2 \mathrm{H}, \mathrm{d}, J\right.$ 9.0, $\left.\mathrm{NCH}_{2}\right), 3.85(2 \mathrm{H}, \mathrm{d}, J$ 9.6, $\mathrm{CH}_{2} \mathrm{~S}$ ); $\delta_{\mathrm{P}}\left[{ }^{1} \mathrm{H}\right]\left(283 \mathrm{MHz} ; \mathrm{CD}_{3} \mathrm{OD}\right) 22.5$ (app qn, $J$ 9.3, NHPS); $\delta_{\mathrm{C}}\left(176 \mathrm{MHz} ; \mathrm{CD}_{3} \mathrm{OD}\right) 140.9,140.5\left(\mathrm{~d},{ }^{3} J_{\mathrm{C}-p} 8.5, C \mathrm{CH}_{2} \mathrm{NH}\right)$, $139.8\left(\mathrm{~d},{ }^{3} J_{C-P} 5.1, C \mathrm{CH}_{2} \mathrm{~S}\right), 139.5,128.5,128.4,127.9,127.8$, 95 $126.7,126.4,126.4,126.2,45.6\left(\mathrm{CH}_{2} \mathrm{NH}\right), 34.6\left(\mathrm{SCH}_{2}\right) ; \mathrm{m} / z\left(\mathrm{ES}^{-}\right.$ 
) $368.08796\left(\mathrm{M}-\mathrm{H} . \mathrm{C}_{20} \mathrm{H}_{19} \mathrm{NO}_{2} \mathrm{PS}\right.$ requires 368.08796).

21c<smiles>CCCSP(=O)([O-])NCc1ccc(-c2ccccc2)cc1</smiles>

$\delta_{\mathrm{H}}\left(700 \mathrm{MHz} ; \mathrm{CD}_{3} \mathrm{OD}\right)$ 7.57-7.56 (2 H, m, Ar-H), 7.53-7.51 (2 H, $\left.{ }_{5} \mathrm{~m} \mathrm{Ar}-\mathrm{H}\right), 7.47-7.45$ (2 H, m, Ar-H), 7.39 (1 H, t, J 7.7, Ar-H), 7.30-7.27 (1 H, m, Ar-H), $4.08\left(2 \mathrm{H}, \mathrm{d}, J\right.$ 9.8, $\left.\mathrm{CH}_{2} \mathrm{NH}\right), 2.63(2 \mathrm{H}$, $\mathrm{dt}, J 10.5$ and 7.4, $\left.\mathrm{SCH}_{2}\right), 1.61\left(2 \mathrm{H}\right.$, app sx, $\left.J 7.4, \mathrm{CH}_{2} \mathrm{CH}_{3}\right)$, $0.95\left(3 \mathrm{H}, \mathrm{t}, J\right.$ 7.4, $\left.\mathrm{CH}_{2} \mathrm{CH}_{3}\right) ; \delta_{\mathrm{P}}\left[{ }^{1} \mathrm{H}\right]\left(283 \mathrm{MHz} ; \mathrm{CD}_{3} \mathrm{OD}\right) 23.8$ (app qn, J 9.7, NHPS); $\delta_{\mathrm{C}}\left(176 \mathrm{MHz} ; \mathrm{CD}_{3} \mathrm{OD}\right) 140.9,140.5$ (d, $\left.{ }_{10}{ }^{3} J_{C-p} 8.5, C_{C H} \mathrm{NH}\right), 139.5,128.4,127.8,126.7,126.4,126.4$, $45.6\left(\mathrm{CH}_{2} \mathrm{NH}\right), 32.4\left(\mathrm{SCH}_{2}\right), 24.2\left(\mathrm{~d},{ }^{3} J_{\mathrm{C}-\mathrm{P}} 6.7, \mathrm{CH}_{2} \mathrm{CH}_{3}\right), 12.8$ $\left(\mathrm{CH}_{2} \mathrm{CH}_{3}\right) ; \mathrm{m} / z\left(\mathrm{ES}^{-}\right) 320.08799\left(\mathrm{M}-\mathrm{H} . \mathrm{C}_{16} \mathrm{H}_{19} \mathrm{NO}_{2} \mathrm{PS}\right.$ requires 320.08796).

22a<smiles></smiles>

$\delta_{\mathrm{H}}\left(700 \mathrm{MHz} ; \mathrm{CD}_{3} \mathrm{OD}\right) 8.72(1 \mathrm{H}, \mathrm{dd}, J 4.2$ and $1.7, \mathrm{Ar}-\mathrm{H}), 8.12$ $(1 \mathrm{H}, \mathrm{dd}, J 8.3$ and 1.7, Ar-H), $8.02(1 \mathrm{H}, \mathrm{d}, J 8.1, \mathrm{Ar}-\mathrm{H}), 7.79(1$ $\mathrm{H}, \mathrm{d}, J$ 7.0, Ar-H), 7.78 (1 H, d, J 7.9, Ar-H), 7.68-7.60 (2 H, m, Ar-H), 7.37-7.31 (4 H, m, Ar-H), 7.27-7.24 (1 H, m, Ar-H), 7.18 $20(1 \mathrm{H}, \mathrm{d}, J 6.8, \mathrm{Ar}-\mathrm{H}), 4.57\left(2 \mathrm{H}, \mathrm{d}, J 11.1, \mathrm{CH}_{2} \mathrm{NH}\right), 4.18(2 \mathrm{H}, \mathrm{d}$, $J$ 7.0, $\left.\mathrm{SCH}_{2}\right) ; \delta_{\mathrm{P}}\left[{ }^{1} \mathrm{H}\right]\left(283 \mathrm{MHz} ; \mathrm{CD}_{3} \mathrm{OD}\right)$ 23.6-23.5 (m, NHPS); $\delta_{\mathrm{C}}\left(176 \mathrm{MHz} ; \mathrm{CD}_{3} \mathrm{OD}\right) 149.4,146.0,138.3$ (d, ${ }^{3} J_{\mathrm{C}-\mathrm{P}} 3.3, \mathrm{SCH}_{2} C$ ), $136.9), 136.1$ (d, $\left.{ }^{3} J_{\mathrm{C}-\mathrm{P}} 11, \mathrm{CCH}_{2} \mathrm{NH}\right), 133.7,131.4,129.6,128.5$, $127.9,127.1,126.9,126.0,125.4,125.1,125.0,124.9,123.5$, ${ }_{25} 43.6 \quad\left(\mathrm{CH}_{2} \mathrm{NH}\right), \quad 32.2 \quad\left(\mathrm{SCH}_{2}\right) ; \quad m / z \quad\left(\mathrm{ES}^{-}\right) \quad 393.0834 \quad(\mathrm{M}-\mathrm{H}$. $\mathrm{C}_{21} \mathrm{H}_{18} \mathrm{~N}_{2} \mathrm{O}_{2}$ PS requires 393.0832).

22b

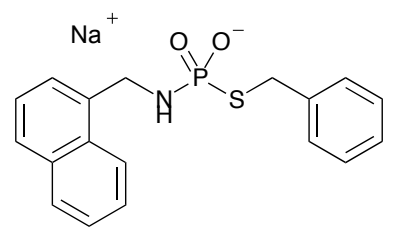

$\delta_{\mathrm{H}}\left(700 \mathrm{MHz} ; \mathrm{CD}_{3} \mathrm{OD}\right) 8.15(1 \mathrm{H}, \mathrm{d}, J 8.5, \mathrm{Ar}-\mathrm{H}), 7.82(1 \mathrm{H}, \mathrm{d}, J$ 30 8.0, Ar-H), 7.72 (1 H, d, J 8.1, Ar-H), 7.48-7.42 (2 H, m, Ar-H), 7.40-7.38 (1 H, m, 2-CH), 7.37-7.33 (3 H, m, Ar-H), $7.23(2 \mathrm{H}$, app t, $J$ 7.6, Ar-H), $7.15(1 \mathrm{H}, \mathrm{t}, J 7.4, \mathrm{Ar}-\mathrm{H}), 4.30(2 \mathrm{H}, \mathrm{d}, J 7.4$, $\left.\mathrm{CH}_{2} \mathrm{NH}\right), 4.30\left(2 \mathrm{H}, \mathrm{d}, J 10.2, \mathrm{SCH}_{2}\right) ; \delta_{\mathrm{P}}\left[{ }^{1} \mathrm{H}\right]\left(283 \mathrm{MHz} ; \mathrm{CD}_{3} \mathrm{OD}\right)$ 22.4-22.2 (m, NHPS); $\delta_{\mathrm{C}}\left(176 \mathrm{MHz} ; \mathrm{CD}_{3} \mathrm{OD}\right) 140.2$ (d, ${ }^{3} J_{C-p} 4.0$, $\left.{ }_{35} \mathrm{CH}_{2} \mathrm{~S}\right), 136.3$ (d, $\left.{ }^{3} J_{\mathrm{C}-\mathrm{P}} 9.0, \mathrm{CH}_{2} \mathrm{NH}\right), 133.9,131.5,128 ., 128.0$, $127.2,127.1,126.3,125.5,125.23,125.15,125.0,123.5,43.6$ $\left(\mathrm{CH}_{2} \mathrm{NH}\right), \quad 34.6 \quad\left(\mathrm{SCH}_{2}\right) ; \quad m / z \quad\left(\mathrm{ES}^{-}\right) \quad 342.07236 \quad(\mathrm{M}-\mathrm{H}$. $\mathrm{C}_{18} \mathrm{H}_{17} \mathrm{NO}_{2}$ PS requires 342.07231). $22 \mathrm{c}$<smiles>CCCSP(=O)([O-])NCc1cccc2ccccc12</smiles>

$\delta_{\mathrm{H}}\left(700 \mathrm{MHz} ; \mathrm{CD}_{3} \mathrm{OD}\right) 8.24(1 \mathrm{H}, \mathrm{d}, J 8.4, \mathrm{Ar}-\mathrm{H}), 7.84(1 \mathrm{H}, \mathrm{d}, J$ 8.1, Ar-H), $7.75(1 \mathrm{H}, \mathrm{d}, J$ 8.3, Ar-H), $7.57(1 \mathrm{H}, \mathrm{d}, J$ 7.1, Ar-H), $7.50(1 \mathrm{H}$, ddd, $J$ 8.3, 6.8 and 1.3, 7-CH), $7.43(1 \mathrm{H}$, ddd, $J$ 8.4, 6.8 and 1.3, Ar-H), $7.40(1 \mathrm{H}, \mathrm{dd}, J$ 8.1, 7.1, Ar-H), $4.51(2 \mathrm{H}, \mathrm{d}$, $\left.{ }_{45} J 7.7, \mathrm{CH}_{2} \mathrm{NH}\right), 2.64\left(2 \mathrm{H}, \mathrm{dt}, J 10.5\right.$ and $\left.7.4, \mathrm{SCH}_{2}\right), 1.63(2 \mathrm{H}$, app sx, J 7.4, $\left.\mathrm{CH}_{2} \mathrm{CH}_{3}\right), 0.95\left(3 \mathrm{H}, \mathrm{t}, J\right.$ 7.4, $\left.\mathrm{CH}_{2} \mathrm{CH}_{3}\right) ; \delta_{\mathrm{P}}\left[{ }^{1} \mathrm{H}\right](283$ $\left.\mathrm{MHz} ; \mathrm{CD}_{3} \mathrm{OD}\right) 23.8-23.6(\mathrm{~m}, \mathrm{NHPS}) ; \delta_{\mathrm{C}}\left(176 \mathrm{MHz} ; \mathrm{CD}_{3} \mathrm{OD}\right)$ $136.3\left(\mathrm{~d},{ }^{3} J_{\mathrm{C}-\mathrm{P}} 9.0, \mathrm{CCH}_{2} \mathrm{NH}\right), 133.9,131.5,128.1,127.2,125.5$, 125.2, 125.1, 125.0, 123.5, 43.6 $\left(\mathrm{CH}_{2} \mathrm{NH}\right), 32.2\left(\mathrm{SCH}_{2}\right), 24.0(\mathrm{~d}$, $\left.{ }_{50}{ }^{3} \mathrm{~J}_{\mathrm{C}-\mathrm{P}} 6.5, \mathrm{CH}_{2} \mathrm{CH}_{3}\right), 12.5\left(\mathrm{CH}_{2} \mathrm{CH}_{3}\right) ; \mathrm{m} / z\left(\mathrm{ES}^{-}\right) 294.07232(\mathrm{M}-\mathrm{H}$. $\mathrm{C}_{14} \mathrm{H}_{17} \mathrm{NO}_{2} \mathrm{PS}$ requires 294.07231).

23a<smiles>O=P([O-])(NCc1ccccc1Sc1ccccc1CO)SCc1cccc2cccnc12</smiles>

$\delta_{\mathrm{H}}\left(700 \mathrm{MHz} ; \mathrm{CD}_{3} \mathrm{OD}\right)$ 8.77-8.75 $(1 \mathrm{H}, \mathrm{m}, \mathrm{Ar}-\mathrm{H}), 8.18-8.16(1 \mathrm{H}$, $55 \mathrm{~m}, \mathrm{Ar}-\mathrm{H}), 7.76(1 \mathrm{H}, \mathrm{d}, J$ 7.1, Ar-H), $7.68(1 \mathrm{H}, \mathrm{d}, J$ 8.1, Ar-H), 7.52-7.48 (2 H, m, Ar-H), 7.41-7.37 (2 H, m, Ar-H), 7.24 (1 H, t, $J 7.5, \mathrm{Ar}-\mathrm{H}), 7.14$ (1 H, t, J 7.5, Ar-H), 7.10 (1 H, t, J 7.5, Ar-H), $7.06(1 \mathrm{H}, \mathrm{t}, J$ 7.6, Ar-H), 6.96-6.92 (2 H, m, Ar-H), $4.62(2 \mathrm{H}, \mathrm{s}$, $\left.\mathrm{CH}_{2} \mathrm{OH}\right), 4.52\left(2 \mathrm{H}, \mathrm{d}, J 11.0, \mathrm{CH}_{2} \mathrm{NH}\right), 3.92(2 \mathrm{H}, \mathrm{d}, J 8.9$, $\left.{ }_{60} \mathrm{SCH}_{2}\right) ; \delta_{\mathrm{P}}\left[{ }^{1} \mathrm{H}\right]\left(283 \mathrm{MHz} ; \mathrm{CD}_{3} \mathrm{OD}\right)$ 23.9-23.8 (m, NHPS); $\delta_{\mathrm{C}}(125$ $\left.\mathrm{MHz} ; \mathrm{CD}_{3} \mathrm{OD}\right) 149.2,145.7,141.9,136.6,133.0,132.8,141.3$ (d, $\left.{ }^{3} J_{\mathrm{C}-\mathrm{P}} 11.2, \mathrm{CCH}_{2} \mathrm{NH}\right), 129.7,129.1,128.4,127.9,127.5,127.5$, 127.4), 127.3, 127.1, 120.9, $61.7\left(\mathrm{CH}_{2} \mathrm{OH}\right), 44.0\left(\mathrm{CH}_{2} \mathrm{NH}\right), 30.1$ $\left(\mathrm{SCH}_{2}\right) ; \mathrm{m} / z\left(\mathrm{ES}^{-}\right) 481.0822\left(\mathrm{M}-\mathrm{H} . \mathrm{C}_{24} \mathrm{H}_{22} \mathrm{~N}_{2} \mathrm{O}_{2} \mathrm{PS}\right.$ requires $\left.{ }_{65} 481.0815\right)$.

23b<smiles>O=P([O-])(Cc1ccccc1)NCc1ccccc1Sc1ccccc1CO</smiles>

$\delta_{\mathrm{H}}\left(700 \mathrm{MHz} ; \mathrm{CD}_{3} \mathrm{OD}\right) 7.56(1 \mathrm{H}, \mathrm{d}, J 7.7, \mathrm{Ar}-\mathrm{H}), 7.54(1 \mathrm{H}, \mathrm{d}, J$ 7.7, Ar-H), 7.28-7.10 (9 H, m, Ar-H), 7.06-7.02 (2 H, m, Ar-H), $704.71(2 \mathrm{H}, \mathrm{s}, \mathrm{CH} 2 \mathrm{OH}), 4.06\left(2 \mathrm{H}, \mathrm{d}, J 9.4, \mathrm{CH}_{2} \mathrm{NH}\right), 3.81(2 \mathrm{H}, \mathrm{d}$, $J$ 9.4, $\left.\mathrm{SCH}_{2}\right) ; \delta_{\mathrm{P}}\left[{ }^{1} \mathrm{H}\right]\left(283 \mathrm{MHz} ; \mathrm{CD}_{3} \mathrm{OD}\right) 22.6$ (app qn, $J$ 9.4, $\mathrm{NHPS}) ; \quad \delta_{\mathrm{C}}\left(176 \mathrm{MHz} ; \mathrm{CD}_{3} \mathrm{OD}\right) 141.9\left(\mathrm{CCH}_{2} \mathrm{OH}\right), 139.9(i-$ $\left.\mathrm{C}_{6} \mathrm{H}_{5} \mathrm{CH}_{2} \mathrm{~S}\right), 133.0,132.8,131.3\left(\mathrm{~d},{ }^{3} J_{\mathrm{C}-\mathrm{P}} 8.1, \mathrm{CCH}_{2} \mathrm{NH}\right), 128.8-$ $126.4(12 \times \mathrm{s}), 126.5,61.3\left(\mathrm{CH}_{2} \mathrm{OH}\right), 46.1\left(\mathrm{CH}_{2} \mathrm{NH}\right), 35.4$ $75\left(\mathrm{SCH}_{2}\right) ; \quad m / z\left(\mathrm{ES}^{-}\right) 430.07103\left(\mathrm{M}-\mathrm{H} . \mathrm{C}_{21} \mathrm{H}_{21} \mathrm{NO}_{3} \mathrm{PS}_{2}\right.$ requires 430.07059).

$23 \mathrm{c}$ 


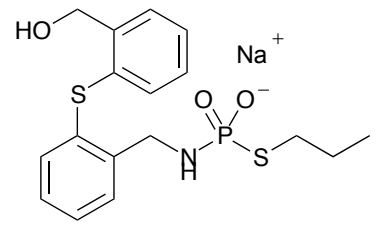

$\delta_{\mathrm{H}}\left(700 \mathrm{MHz} ; \mathrm{CD}_{3} \mathrm{OD}\right) 7.64(1 \mathrm{H}, \mathrm{d}, J$ 7.7, Ar-H), $7.54(1 \mathrm{H}, \mathrm{d}, J$ 7.7, Ar-H), 7.28 (1 H, t, $J$ 7.5, Ar-H), $7.25(1 \mathrm{H}, \mathrm{t}, J$ 7.5, Ar-H), $7.17(1 \mathrm{H}, \mathrm{t}, J 7.5, \mathrm{Ar}-\mathrm{H}), 7.14(1 \mathrm{H}, \mathrm{t}, J 7.5, \mathrm{Ar}-\mathrm{H}), 7.06(1 \mathrm{H}, \mathrm{d}$, ${ }_{5} J$ 7.7, Ar-H), $7.05\left(1 \mathrm{H}, \mathrm{d}, J\right.$ 7.7, Ar-H), $4.72\left(2 \mathrm{H}, \mathrm{s}, \mathrm{CH}_{2} \mathrm{OH}\right)$, $4.17\left(2 \mathrm{H}, \mathrm{d}, J 9.4, \mathrm{CH}_{2} \mathrm{NH}\right), 2.56\left(2 \mathrm{H}, \mathrm{dt}, J 10.5\right.$ and $\left.7.4, \mathrm{SCH}_{2}\right)$, $1.60\left(2 \mathrm{H}\right.$, app sx, $\left.J 7.4, \mathrm{CH}_{2} \mathrm{CH}_{3}\right), 0.90\left(3 \mathrm{H}, \mathrm{t}, J 7.4, \mathrm{CH}_{2} \mathrm{CH}_{3}\right)$; $\delta_{\mathrm{P}}\left[{ }^{1} \mathrm{H}\right]\left(283 \mathrm{MHz} ; \mathrm{CD}_{3} \mathrm{OD}\right) 23.9$ (app qn, $J$ 9.8, NHPS); $\delta_{\mathrm{C}}(176$ $\left.\mathrm{MHz} ; \mathrm{CD}_{3} \mathrm{OD}\right) 141.9\left(\mathrm{CCH}_{2} \mathrm{OH}\right), 133.0,132.8,131.3\left(\mathrm{~d},{ }^{3} J_{\mathrm{C}-\mathrm{P}}\right.$ $\left.1011.2, \quad \mathrm{CCH}_{2} \mathrm{NH}\right), 129.1, \quad 127.9,127.5,127.4, \quad 127.3,62.3$ $\left(\mathrm{CH}_{2} \mathrm{OH}\right), 46.1\left(\mathrm{CH}_{2} \mathrm{NH}\right), 35.4\left(\mathrm{SCH}_{2}\right), 27.2$ (d, ${ }^{3} J_{\mathrm{C}-\mathrm{P}} 6.2$, $\left.\mathrm{CH}_{2} \mathrm{CH}_{3}\right), \quad 16.8 \quad\left(\mathrm{CH}_{2} \mathrm{CH}_{3}\right) ; \quad m / z \quad\left(\mathrm{ES}^{-}\right) \quad 382.07098 \quad(\mathrm{M}-\mathrm{H}$. $\mathrm{C}_{17} \mathrm{H}_{21} \mathrm{NO}_{3} \mathrm{PS}_{2}$ requires 382.07060).

24a

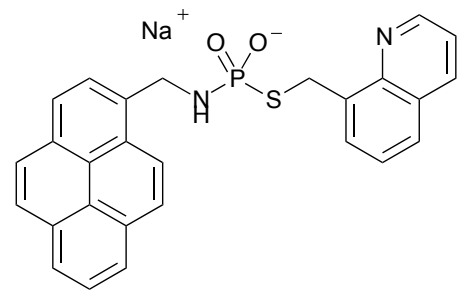

$\delta_{\mathrm{H}}\left(700 \mathrm{MHz} ; \mathrm{CD}_{3} \mathrm{OD}\right) 8.66(1 \mathrm{H}, \mathrm{dd}, J 4.1$ and $1.7, \mathrm{Ar}-\mathrm{H}), 8.24$ (1 H, d, J 9.2, Ar-H), $8.11(1 \mathrm{H}, \mathrm{d}, J$ 7.5, Ar-H), $8.10(1 \mathrm{H}, \mathrm{d}, J$ 7.6, Ar-H), 7.99-7.89 (6 H, m, Ar-H), 7.76 (1 H, d, J 7.0, Ar-H), 7.73 (1 H, d, J 7.7, Ar-H), $7.53(1 \mathrm{H}, \mathrm{d}, J$ 8.2, Ar-H), 7.32-7.29 (1 $\left.{ }_{20} \mathrm{H}, \mathrm{m}, \mathrm{Ar}-\mathrm{H}\right), 7.21(1 \mathrm{H}, \mathrm{dd}, J 8.2$ and 4.1, Ar-H), $4.58(2 \mathrm{H}, \mathrm{d}, J$ 11.7, $\left.\mathrm{CH}_{2} \mathrm{NH}\right), 4.44\left(2 \mathrm{H}, \mathrm{d}, J 7.4, \mathrm{SCH}_{2}\right) ; \delta_{\mathrm{P}}\left[{ }^{1} \mathrm{H}\right](283 \mathrm{MHz}$; $\left.\mathrm{CD}_{3} \mathrm{OD}\right)$ 23.4-23.2 (m, NHPS); $\delta_{\mathrm{C}}\left(125 \mathrm{MHz} ; \mathrm{CD}_{3} \mathrm{OD}\right)$ 149.3, $145.9,137.8\left(\mathrm{~d},{ }^{3} J_{\mathrm{C}-\mathrm{P}}\right.$ not resolved, $\left.\mathrm{SCH}_{2} \mathrm{C}\right), 134.0\left(\mathrm{~d},{ }^{3} J_{\mathrm{C}-\mathrm{P}} 11.2\right.$, $\left.\mathrm{CCH}_{2} \mathrm{NH}\right), 136.6,131.3,130.8,130.5,128.5,129.5,128.4,127.0$, ${ }_{25} 126.7,126.3,126.1,125.4,125.8,124.4,124.4,124.2,123.2$, 120.7, $44.0\left(\mathrm{CH}_{2} \mathrm{NH}\right), 30.1\left(\mathrm{SCH}_{2}\right) ; m / z\left(\mathrm{ES}^{-}\right) 467.0996(\mathrm{M}-\mathrm{H}$. $\mathrm{C}_{27} \mathrm{H}_{20} \mathrm{~N}_{2} \mathrm{O}_{2}$ PS requires 467.0988). 24b

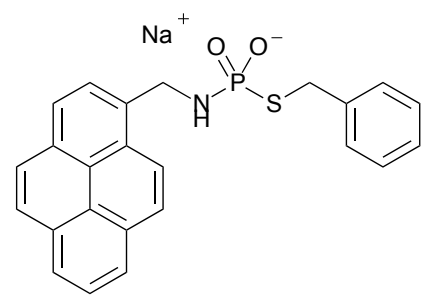

${ }_{30} \delta_{\mathrm{H}}\left(700 \mathrm{MHz} ; \mathrm{CD}_{3} \mathrm{OD}\right) 8.39(1 \mathrm{H}, \mathrm{d}, J 9.2, \mathrm{Ar}-\mathrm{H}), 8.14(1 \mathrm{H}, \mathrm{t}, J$ 7.5, Ar-H), 8.09-8.05 (1 H, m, Ar-H), 8.06 (1 H, d, J 7.7, Ar-H), $8.00(1 \mathrm{H}, \mathrm{s}, \mathrm{Ar}-\mathrm{H}), 7.97-7.93(1 \mathrm{H}, \mathrm{m}, \mathrm{Ar}-\mathrm{H}), 7.30(1 \mathrm{H}, \mathrm{d}, J 7.3$, Ar-H), 7.18 (1 H, t, J 7.6, Ar-H), 7.12 (1 H, t, J 7.4, Ar-H), 4.56 $\left(2 \mathrm{H}, \mathrm{d}, J 7.7, \mathrm{CH}_{2} \mathrm{NH}\right), 3.89\left(2 \mathrm{H}, \mathrm{d}, J 10.2, \mathrm{SCH} \mathrm{H}_{2}\right) ; \delta_{\mathrm{P}}\left[{ }^{1} \mathrm{H}\right](283$ $\left.{ }_{35} \mathrm{MHz} ; \mathrm{CD}_{3} \mathrm{OD}\right)$ 22.6-22.3 (m, NHPS); $\delta_{\mathrm{C}}\left(176 \mathrm{MHz} ; \mathrm{CD}_{3} \mathrm{OD}\right)$ $140.1\left(\mathrm{CCH}_{2} \mathrm{NH}\right), 134.2\left(\mathrm{CH}_{2} \mathrm{~S}\right), 131.3,130.8,130.5,128.5$, $128.4,127.9,127.0,126.9,126.5,126.4,126.2,125.5,124.5$, 124.4, 123.1, $43.7\left(\mathrm{CH}_{2} \mathrm{NH}\right), 34.5\left(\mathrm{SCH}_{2}\right) ; \mathrm{m} / z\left(\mathrm{ES}^{-}\right) 416.08815$ (M-H. $\mathrm{C}_{24} \mathrm{H}_{19} \mathrm{NO}_{2} \mathrm{PS}$ requires 416.08796).
${ }_{40} \mathbf{2 4 c}$<smiles>CCCSP(=O)([O-])NCc1ccc2ccc3cccc4ccc1c2c34</smiles>

$\delta_{\mathrm{H}}\left(700 \mathrm{MHz} ; \mathrm{CD}_{3} \mathrm{OD}\right) 8.39(1 \mathrm{H}, \mathrm{d}, J$ 9.2, $\mathrm{ArH}), 8.16-8.13(2 \mathrm{H}$, $\mathrm{m}, \mathrm{Ar}-\mathrm{H}), 8.12-8.11(2 \mathrm{H}, \mathrm{m}, \mathrm{Ar}-\mathrm{H}), 8.09$ (1 H, d, $J$ 9.2, Ar-H), 8.01-7.99 (2 H, m, Ar-H), 7.96 (1 H, t, J 7.6, Ar-H), $4.46(2 \mathrm{H}, \mathrm{d}$, $\left.{ }_{45} J 7.7, \mathrm{CH}_{2} \mathrm{NH}\right), 2.63\left(2 \mathrm{H}, \mathrm{dt}, J 9.8\right.$ and $\left.7.4, \mathrm{SCH}_{2}\right), 1.60(2 \mathrm{H}$, app sx, $J$ 7.4, $\left.\mathrm{CH}_{2} \mathrm{CH}_{3}\right), 0.94\left(3 \mathrm{H}, \mathrm{t}, J 7.4, \mathrm{CH}_{2} \mathrm{CH}_{3}\right) ; \delta_{\mathrm{P}}\left[{ }^{1} \mathrm{H}\right](283$ $\left.\mathrm{MHz} ; \mathrm{CD}_{3} \mathrm{OD}\right)$ 23.7-23.5 (m, NHPS); $\delta_{\mathrm{C}}\left(176 \mathrm{MHz} ; \mathrm{CD}_{3} \mathrm{OD}\right)$ $134.4\left(\mathrm{~d},{ }^{3} J_{\mathrm{C}-\mathrm{P}} 11.7, \mathrm{CCH}_{2} \mathrm{NH}\right), 131.3,130.8,130.5,128.5$, $127.0,126.9,126.5,126.4,125.5,124.5,124.4,124.3,44.1$ ${ }_{50}\left(\mathrm{CH}_{2} \mathrm{NH}\right), 32.5\left(\mathrm{SCH}_{2}\right), 24.2\left(\mathrm{~d},{ }^{3} J_{\mathrm{C}-\mathrm{P}} \quad 6.7, \mathrm{CH}_{2} \mathrm{CH}_{3}\right), 12.7$ $\left(\mathrm{CH}_{2} \mathrm{CH}_{3}\right) ; \mathrm{m} / z\left(\mathrm{ES}^{-}\right) 368.08837\left(\mathrm{M}-\mathrm{H} . \mathrm{C}_{20} \mathrm{H}_{19} \mathrm{NO}_{2} \mathrm{PS}\right.$ requires 368.08796).

25a<smiles>CN(Cc1c2ccccc2cc2ccccc12)P(=O)([O-])SCc1cccc2cccnc12</smiles>

${ }_{55} \delta_{\mathrm{H}}\left(700 \mathrm{MHz} ; \mathrm{CD}_{3} \mathrm{OD}\right) 8.67(1 \mathrm{H}, \mathrm{dd}, J 4.1$ and $1.7, \mathrm{Ar}-\mathrm{H}), 8.23$ (1 H, d, J 9.1, Ar-H), 8.08 (2 H, t, J 7.7, Ar-H), 7.99-7.89 (6 H, m, Ar-H), 7.76 (1 H, d, J 7.0, Ar-H), 7.74 (1 H, d, J 7.7, Ar-H), 7.53 (1 H, d, $J$ 8.1, Ar-H), 7.32-7.29 (1 H, m Ar-H), $7.20(1 \mathrm{H}$, $\mathrm{dd}, J 8.2$ and 4.1, Ar-H), $4.59\left(2 \mathrm{H}, \mathrm{d}, J 11.5, \mathrm{CH}_{2} \mathrm{~N}\right), 4.44(2 \mathrm{H}$, ${ }_{60} \mathrm{~d}, J$ 7.4, $\left.\mathrm{SCH}_{2}\right), 3.30-3.28\left(3 \mathrm{H}, \mathrm{m}, \mathrm{NCH}_{3}\right) ; \delta_{\mathrm{P}}\left[{ }^{1} \mathrm{H}\right](283 \mathrm{MHz}$; $\left.\mathrm{CD}_{3} \mathrm{OD}\right) 23.3-23.1(\mathrm{~m}, \mathrm{NPS}) ; \delta_{\mathrm{C}}\left(176 \mathrm{MHz} ; \mathrm{CD}_{3} \mathrm{OD}\right)$ aromatic signals could not be assigned owing to the level of heterogeneity of this particular sample, $43.8\left(\mathrm{CH}_{2} \mathrm{~N}\right), 38.6-37.8\left(\mathrm{~m}, \mathrm{NCH}_{3}\right)$, $29.9\left(\mathrm{SCH}_{2}\right) ; \mathrm{m} / z\left(\mathrm{ES}^{-}\right) 457.1153\left(\mathrm{M}-\mathrm{H} . \mathrm{C}_{26} \mathrm{H}_{22} \mathrm{~N}_{2} \mathrm{O}_{2} \mathrm{PS}\right.$ requires $\left.{ }_{65} 457.1145\right)$.

25b<smiles>O=P([O-])([N+]Cc1c2ccccc2cc2ccccc12)SCc1ccccc1</smiles>

$\delta_{\mathrm{H}}\left(700 \mathrm{MHz} ; \mathrm{CD}_{3} \mathrm{OD}\right) 8.60(2 \mathrm{H}, \mathrm{d}, J 8.8, \mathrm{Ar}-\mathrm{H}), 8.40(1 \mathrm{H}, \mathrm{s}$, Ar-H), 7.97 (2 H, d, J 8.5, Ar-H), 7.52 (2 H, d, J 7.5, Ar-H), 7.49$707.45(2 \mathrm{H}, \mathrm{m}, \mathrm{Ar}-\mathrm{H}), 7.43-7.40(2 \mathrm{H}, \mathrm{m}, \operatorname{Ar}-\mathrm{H}), 7.33(2 \mathrm{H}, \mathrm{t}, J$ 7.6,Ar-H), $7.26(1 \mathrm{H}, \mathrm{t}, J$ 7.4, Ar-H), $5.01(2 \mathrm{H}, \mathrm{d}, J 3.8$, $\left.\mathrm{CH}_{2} \mathrm{NH}\right), 4.15\left(2 \mathrm{H}, \mathrm{d}, J 10.1, \mathrm{SCH}_{2}\right), 2.21(3 \mathrm{H}, \mathrm{d}, J 12.2$, $\left.\mathrm{NCH}_{3}\right) ; \quad \delta_{\mathrm{P}}\left[{ }^{1} \mathrm{H}\right]\left(283 \mathrm{MHz} ; \mathrm{CD}_{3} \mathrm{OD}\right) \quad 23.7-23.4 \quad$ (m, NHPS); $\delta_{\mathrm{C}}\left(176 \mathrm{MHz} ; \mathrm{CD}_{3} \mathrm{OD}\right) 140.9\left(\mathrm{~d},{ }^{3} J_{C-p} 5.4\right), 131.7,131.6,129.7(\mathrm{~d}$, $\left.75{ }^{3} J_{\mathrm{C}-\mathrm{P}} 10.7\right), 128.7,128.5,127.6,127.3,126.3,125.5,124 ., 124.7$, $44.5\left(\mathrm{CH}_{2} \mathrm{NH}\right), 34.3\left(\mathrm{SCH}_{2}\right), 32.4\left(\mathrm{NCH}_{3}\right) ; \mathrm{m} / z\left(\mathrm{ES}^{-}\right) 406.10419$ (M-H. $\mathrm{C}_{23} \mathrm{H}_{21} \mathrm{NO}_{2}$ PS requires 406.10361).

25c 
<smiles>CCCSP(=O)([O-])N(C)Cc1c2ccccc2cc2ccccc12</smiles>

$\delta_{\mathrm{H}}\left(700 \mathrm{MHz} ; \mathrm{CD}_{3} \mathrm{OD}\right) 8.74(2 \mathrm{H}, \mathrm{d}, J$ 8.9, Ar-H), $8.42(1 \mathrm{H}, \mathrm{s}$, Ar-H), 7.99 ( 2 H, d, $J$ 8.4, Ar-H), 7.50 ( 2 H, $2 \times \mathrm{t}, J 7.4,2$ - and 7$\mathrm{CH})$, 7.51-7.48 (2 H, m, Ar-H), 7.44-7.41 (2 H, m, Ar-H) 5.17 (2 $\left.{ }_{5} \mathrm{H}, \mathrm{d}, J 3.7, \mathrm{CH}_{2} \mathrm{NH}\right), 2.85\left(2 \mathrm{H}, \mathrm{dt}, J 9.8\right.$ and 7.4, $\left.\mathrm{SCH}_{2}\right), 2.30$ (3 $\left.\mathrm{H}, \mathrm{d}, J 12.1, \mathrm{NCH}_{3}\right), 1.75\left(2 \mathrm{H}\right.$, app sx, $J$ 7.4, $\left.\mathrm{CH}_{2} \mathrm{CH}_{3}\right), 1.04(3$ $\mathrm{H}, \mathrm{t}, J$ 7.4, $\left.\mathrm{CH}_{2} \mathrm{CH}_{3}\right) ; \delta_{\mathrm{P}}\left[{ }^{1} \mathrm{H}\right]\left(283 \mathrm{MHz} ; \mathrm{CD}_{3} \mathrm{OD}\right)$ 24.9-24.6 (m, $\mathrm{NHPS}) ; \delta_{\mathrm{C}}\left(176 \mathrm{MHz} ; \mathrm{CD}_{3} \mathrm{OD}\right) 131.5,131.4,129.4$ (d, $\left.{ }^{3} J_{\mathrm{C}-\mathrm{P}} 9.1\right)$, $128.5,127.1,125.3,124.8,124.4,44.2\left(\mathrm{CH}_{2} \mathrm{NH}\right), 32.4\left(\mathrm{SCH}_{2}\right)$, $1031.8\left(\mathrm{NCH}_{3}\right), 24.7$ (d, $\left.{ }^{3} \mathrm{~J}_{\mathrm{C}-\mathrm{P}} 5.5, \mathrm{CH}_{2} \mathrm{CH}_{3}\right), 12.7\left(\mathrm{CH}_{2} \mathrm{CH}_{3}\right) ; \mathrm{m} / \mathrm{z}$ (ES $)^{-} 358.10394\left(\mathrm{M}-\mathrm{H} . \mathrm{C}_{19} \mathrm{H}_{21} \mathrm{NO}_{2} \mathrm{PS}\right.$ requires 358.10361). 26a

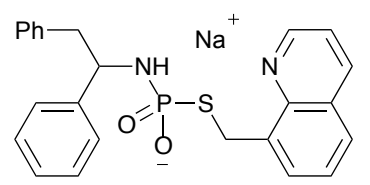

$\delta_{\mathrm{H}}\left(700 \mathrm{MHz} ; \mathrm{CD}_{3} \mathrm{OD}\right) 8.79(1 \mathrm{H}, \mathrm{dd}, J 4.2$ and $1.8, \mathrm{Ar}-\mathrm{H}), 8.21$ $15(1 \mathrm{H}, \mathrm{dd}, J 8.2$ and 1.8, Ar-H), $7.71(1 \mathrm{H}, \mathrm{dd}, J 8.2$ and 1.3, ArH), 7.62-7.60 (1 H, m, Ar-H), 7.43 (1 H, dd, J 8.2 and 4.2, Ar-H), 7.39 ( $1 \mathrm{H}, \mathrm{dd}, J 8.1$ and 7.2, Ar-H), 7.10-6.96 (8 H, m, Ar-H), 6.81-6.79 (2 H, m, Ar-H), $4.51\left(1 \mathrm{H}, J 12.7\right.$ and 9.6, $\left.\mathrm{SCH}_{2}\right), 4.40-$ $4.35\left(1 \mathrm{H}, \mathrm{m}, \mathrm{CH}_{2} \mathrm{CH}\right), 4.31\left(1 \mathrm{H}, J 12.7\right.$ and $\left.10.3, \mathrm{SCH}_{2}\right), 3.19$ (1 ${ }_{20} \mathrm{H}, J 13.1$ and 4.6, $\left.\mathrm{CH}_{2} \mathrm{CH}\right), 2.74\left(1 \mathrm{H}, J 13.1\right.$ and 9.5, $\left.\mathrm{CH}_{2} \mathrm{CH}\right)$; $\delta_{\mathrm{P}}\left[{ }^{1} \mathrm{H}\right]\left(283 \mathrm{MHz} ; \mathrm{CD}_{3} \mathrm{OD}\right) 21.7-21.5(\mathrm{~m}, \mathrm{NH} P \mathrm{~S}) ; \delta_{\mathrm{C}}(176 \mathrm{MHz}$; $\mathrm{CD}_{3} \mathrm{OD}$ ) 149.2, 149.0, 145.9, 144.1-144.0 (unresolved, $C \mathrm{CHNH}$ ), 138.5, 137.8-137.7 (unresolved, $\mathrm{SCH}_{2} C$ ), 136.6, 136.4, 129.7$125.8(11 \times \mathrm{s}), 120.9,120.7,57.9-57.6$ (unresolved, $\mathrm{CH}_{2} \mathrm{CH}$ ), 25 45.1-44.9 (unresolved, $\mathrm{CH}_{2} \mathrm{CH}$ ), 30.1-29.8 (unresolved, $\mathrm{SCH}_{2}$ ); $\mathrm{m} / z\left(\mathrm{ES}^{-}\right) 433.1143\left(\mathrm{M}-\mathrm{H} . \mathrm{C}_{24} \mathrm{H}_{22} \mathrm{~N}_{2} \mathrm{O}_{2} \mathrm{PS}\right.$ requires 433.1145). 26b

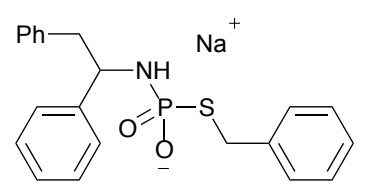

$\delta_{\mathrm{H}}\left(700 \mathrm{MHz} ; \mathrm{CD}_{3} \mathrm{OD}\right)$ 7.19-7.03 (13 H, m, Ar-H), 6.95-6.92 (2 $\left.{ }_{30} \mathrm{H}, \mathrm{m}, \mathrm{Ar}-\mathrm{H}\right), 4.46\left(1 \mathrm{H}\right.$, ddd, $J 11.2,9.2$ and 5.2, $\left.\mathrm{CH}_{2} \mathrm{CH}\right), 3.60(1$ $\mathrm{H}, J 12$ and 6.9, $\left.\mathrm{SCH}_{2}\right), 3.47\left(1 \mathrm{H}, J 12\right.$ and 7.7, $\left.\mathrm{SCH}_{2}\right), 3.22(1$ $\mathrm{H}, J 13.1$ and 5.2, $\left.\mathrm{CH}_{2} \mathrm{CH}\right), 2.88\left(1 \mathrm{H}, J 13.1\right.$ and $\left.9.0, \mathrm{CH}_{2} \mathrm{CH}\right)$; $\delta_{\mathrm{P}}\left[{ }^{1} \mathrm{H}\right]\left(283 \mathrm{MHz} ; \mathrm{CD}_{3} \mathrm{OD}\right) 20.9-20.8(\mathrm{~m}, \mathrm{NHPS}) ; \delta_{\mathrm{C}}(176 \mathrm{MHz}$; $\left.\mathrm{CD}_{3} \mathrm{OD}\right) 144.4\left(\mathrm{~d},{ }^{3} J_{\mathrm{C}-\mathrm{P}} 3.7, \mathrm{CCHNH}\right), 139.2$ (d, ${ }^{3} J_{\mathrm{C}-\mathrm{P}} 7.8$, $\left.{ }_{35} \mathrm{SCH}_{2} \mathrm{C}\right), 138.5,129.5-125.5(6 \times \mathrm{s}), 57.7\left(\mathrm{CH}_{2} \mathrm{CH}\right), 45.7-45.4$ (unresolved, $\mathrm{CH}_{2} \mathrm{CH}$ ), 34.5-34.3 (unresolved, $\left.\mathrm{SCH}_{2}\right) ; \mathrm{m} / \mathrm{z}\left(\mathrm{ES}^{-}\right.$) $382.10338\left(\mathrm{M}-\mathrm{H} . \mathrm{C}_{21} \mathrm{H}_{21} \mathrm{NO}_{2} \mathrm{PS}\right.$ requires 382.10361$)$.

26c

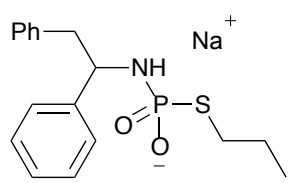

${ }_{40} \delta_{\mathrm{H}}\left(700 \mathrm{MHz} ; \mathrm{CD}_{3} \mathrm{OD}\right) 7.18-7.03(8 \mathrm{H}, \mathrm{m}, \mathrm{Ar}-\mathrm{H}), 6.97-6.94(2 \mathrm{H}$, $\mathrm{m}, \mathrm{Ar}-\mathrm{H}), 4.45\left(1 \mathrm{H}\right.$, ddd, $J 14.0,11.2$ and 5.6, $\left.\mathrm{CH}_{2} \mathrm{CH}\right), 3.22(1$ $\mathrm{H}, J 13.2$ and 5.3, $\left.\mathrm{CH}_{2} \mathrm{CH}\right), 2.93\left(1 \mathrm{H}, \mathrm{CH}_{2} \mathrm{CH}\right), 2.37-2.22(\mathrm{~m}$, $\left.\mathrm{SCH}_{2}\right), 1.42-1.32\left(2 \mathrm{H}, \mathrm{m}, \mathrm{CH}_{2} \mathrm{CH}_{3}\right), 0.79\left(3 \mathrm{H}, \mathrm{t}, \mathrm{J} 7.4, \mathrm{CH}_{3}\right)$; $\delta_{\mathrm{P}}\left[{ }^{1} \mathrm{H}\right]\left(283 \mathrm{MHz} ; \mathrm{CD}_{3} \mathrm{OD}\right)$ 22.4-22.3 (m, NHPS); $\delta_{\mathrm{C}}(176 \mathrm{MHz}$; $\left.{ }_{45} \mathrm{CD}_{3} \mathrm{OD}\right) 144.4$ (d, ${ }^{3} J_{\mathrm{C}-\mathrm{P}}$ not resolved, $\left.C \mathrm{CHNH}\right), 138.5,129.4$, $127.4(2 \times \mathrm{s}), 126.8,126.0,125.5,57.6\left(\mathrm{CH}_{2} \mathrm{CH}\right), 45.5\left(\mathrm{~d},{ }^{3} J_{\mathrm{C}-\mathrm{P}}\right.$ 5.6, $\left.\mathrm{CH}_{2} \mathrm{CH}\right), 32.0\left(\mathrm{SCH}_{2}\right), 23.6\left(\mathrm{~d},{ }^{3} \mathrm{~J}_{\mathrm{C}-\mathrm{P}} 7.4, \mathrm{CH}_{2} \mathrm{CH}_{3}\right), 12.5$ $\left(\mathrm{CH}_{3}\right) ; \mathrm{m} / \mathrm{z}\left(\mathrm{ES}^{-}\right) 334.10399\left(\mathrm{M}-\mathrm{H} . \mathrm{C}_{17} \mathrm{H}_{21} \mathrm{NO}_{2} \mathrm{PS}\right.$ requires 335.10361). ${ }_{50} \mathbf{2 7} \mathbf{a}$<smiles></smiles>

$\delta_{\mathrm{H}}\left(700 \mathrm{MHz} ; \mathrm{CD}_{3} \mathrm{OD}\right) 8.80(1 \mathrm{H}, \mathrm{dd}, J 4.2$ and $1.7, \mathrm{Ar}-\mathrm{H}), 8.25$ $(1 \mathrm{H}, \mathrm{dd}, J 8.2$ and 1.7, Ar-H), $7.82(1 \mathrm{H}, \mathrm{d}, J$ 7.1, Ar-H), 7.76 (1 $\mathrm{H}, \mathrm{d}, J$ 8.1, Ar-H), 7.49-7.42 (2 H, m, Ar-H), 7.20-7.11 (5 H, m, $\left.{ }_{55} \mathrm{Ar}-\mathrm{H}\right), 4.55\left(2 \mathrm{H}, \mathrm{d}, J 11.2, \mathrm{SCH}_{2}\right), 3.74\left(2 \mathrm{H}, \mathrm{d}, J 7.7, \mathrm{CH}_{2} \mathrm{NH}\right)$; $\delta_{\mathrm{P}}\left[{ }^{1} \mathrm{H}\right]\left(283 \mathrm{MHz} ; \mathrm{CD}_{3} \mathrm{OD}\right)$ 23.7-23.5 (m, NHPS); $\delta_{\mathrm{C}}(176 \mathrm{MHz}$; $\left.\mathrm{CD}_{3} \mathrm{OD}\right) 149.2,145.8,141.0-140.8$ (m, ${ }^{3} J_{\mathrm{C}-\mathrm{P}}$ not resolved, $\mathrm{CCH}_{2} \mathrm{NH}$ ), 138.2-138.0 (m, ${ }^{3} J_{\mathrm{C}-\mathrm{P}}$ not resolved, $\mathrm{SCH}_{2} \mathrm{C}$ ), 136.6, $129.7,128.6,127.7,127.2,126.9,126.1(2 \times \mathrm{s}), 120.9,45.8$ ${ }_{60}\left(\mathrm{CH}_{2} \mathrm{NH}\right), \quad 29.8 \quad\left(\mathrm{SCH}_{2}\right) ; \quad m / z \quad\left(\mathrm{ES}^{-}\right) \quad 343.0678 \quad(\mathrm{M}-\mathrm{H}$. $\mathrm{C}_{17} \mathrm{H}_{16} \mathrm{~N}_{2} \mathrm{O}_{2} \mathrm{PS}$ requires 343.0678). 28a<smiles>C=CCNP(=O)([O-])SCc1cccc2cccnc12</smiles>

$\delta_{\mathrm{H}}\left(500 \mathrm{MHz} ; \mathrm{CD}_{3} \mathrm{OD}\right) 8.89(1 \mathrm{H}, \mathrm{dd}, J 4.2$ and $1.8, \mathrm{Ar}-\mathrm{H}), 8.30$ $65(1 \mathrm{H}, \mathrm{dd}, J 8.3$ and 1.7, Ar-H), 7.90-7.86 (1 H, m, Ar-H), 7.82 (1 $\mathrm{H}$, dd, $J$ 8.2 and 1.3, Ar-H), 7.56-7.49 (2 H, m, Ar-H), 5.83-5.72 $\left(1 \mathrm{H}, \mathrm{m}, \mathrm{CH}_{2}=\mathrm{CH}\right), 4.99(1 \mathrm{H}, \mathrm{dq}, J 17.1$ and $1.7, \mathrm{CHH}=\mathrm{CH})$, 4.91-4.87 $(1 \mathrm{H}, \mathrm{m}, \mathrm{CH} H=\mathrm{CH}), 4.57\left(2 \mathrm{H}, \mathrm{d}, J 11.1, \mathrm{SCH}_{2}\right), 3.23$ $\left(2 \mathrm{H}\right.$, ddt, $J 8.8,5.7$ and $\left.1.5, \mathrm{CH}_{2} \mathrm{NH}\right) ; \delta_{\mathrm{P}}\left[{ }^{1} \mathrm{H}\right]\left(283 \mathrm{MHz} ; \mathrm{CD}_{3} \mathrm{OD}\right)$ 70 23.8-23.6 (m, NHPS); $\delta_{\mathrm{C}}\left(125 \mathrm{MHz}\right.$; $\left.\mathrm{CD}_{3} \mathrm{OD}\right) 149.5,146.0,138.3$ $\left(\mathrm{d},{ }^{3} J_{\mathrm{C}-\mathrm{P}} 4.6, \mathrm{SCH}_{2} C\right), 137.5\left(\mathrm{~d},{ }^{3} J_{\mathrm{C}-\mathrm{P}} 9.9, \mathrm{CHCH}_{2}\right), 136.9,130.0$, 128.9, 127.2, 126.4, 121.2, $113.7\left(\mathrm{CH}_{2}=\mathrm{CH}\right), 44.8\left(\mathrm{CH}_{2} \mathrm{NH}\right), 30.0$ (d, $\left.{ }^{2} J_{\text {C-P }} 2.7, \mathrm{SCH}_{2}\right) ; m / z\left(\mathrm{ES}^{-}\right) 293.0522\left(\mathrm{M}-\mathrm{H} . \mathrm{C}_{13} \mathrm{H}_{14} \mathrm{~N}_{2} \mathrm{O}_{2} \mathrm{PS}\right.$ requires 293.0519).

$7529 a$<smiles>CCCNP(=O)([O-])SCc1cccc2cccnc12</smiles>

$\delta_{\mathrm{H}}\left(500 \mathrm{MHz} ; \mathrm{CD}_{3} \mathrm{OD}\right) 8.89(1 \mathrm{H}, \mathrm{dd}, J 4.2$ and $1.8, \mathrm{Ar}-\mathrm{H}), 8.30$ $(1 \mathrm{H}, \mathrm{dd}, J 8.3$ and 1.7, Ar-H), $7.89(1 \mathrm{H}, \mathrm{dd}, J 7.1$ and 1.0, Ar-

This journal is (C) The Royal Society of Chemistry [year]

Journal Name, [year], [vol], 00-00 1/3 
H), $7.82(1 \mathrm{H}, \mathrm{dd}, J 8.2$ and 1.2, Ar-H), 7.56-7.49 (2H, m, Ar-H), $4.56\left(2 \mathrm{H}, \mathrm{d}, J 11.1, \mathrm{SCH}_{2}\right), 2.57\left(2 \mathrm{H}, \mathrm{dt}, J 8.7\right.$ and $\left.7.4, \mathrm{CH}_{2} \mathrm{NH}\right)$, $1.30\left(2 \mathrm{H}\right.$, app sx, $\left.J 7.4, \mathrm{CH}_{3} \mathrm{CH}_{2}\right), 0.77\left(3 \mathrm{H}, \mathrm{t}, J 7.4, \mathrm{CH}_{3} \mathrm{CH}_{2}\right)$; $\delta_{\mathrm{P}}\left[{ }^{1} \mathrm{H}\right]\left(283 \mathrm{MHz} ; \mathrm{CD}_{3} \mathrm{OD}\right) 24.2-24.0(\mathrm{~m}, \mathrm{NHPS}) ; \delta_{\mathrm{C}}(125 \mathrm{MHz}$; $\left.{ }_{5} \mathrm{CD}_{3} \mathrm{OD}\right) 149.5,146.1,138.3$ (d, ${ }^{3} J_{\mathrm{C}-\mathrm{P}} 4.6, \mathrm{SCH}_{2} \mathrm{C}$ ), 136.9, 129.9, $128.8,127.2,126.4,121.2,43.8\left(\mathrm{CH}_{2} \mathrm{NH}\right), 30.1$ (d, ${ }^{2} J_{\mathrm{C}-\mathrm{P}} 2.7$, $\left.\mathrm{SCH}_{2}\right), 24.4$ (d, $\left.{ }^{2} J_{\mathrm{C}-\mathrm{P}} 9.1, \mathrm{CH}_{3} \mathrm{CH}_{2}\right), 10.7\left(\mathrm{CH}_{3} \mathrm{CH}_{2}\right) ; \mathrm{m} / \mathrm{z}\left(\mathrm{ES}^{-}\right)$ 295.0677 (M-H. $\mathrm{C}_{13} \mathrm{H}_{16} \mathrm{~N}_{2} \mathrm{O}_{2} \mathrm{PS}$ requires 295.0675) 29b

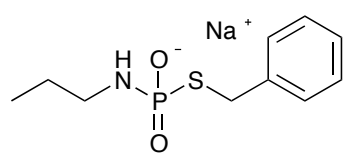

$\delta_{\mathrm{H}}\left(700 \mathrm{MHz} ; \mathrm{CD}_{3} \mathrm{OD}\right) 7.38(2 \mathrm{H}, \mathrm{d}, J$ 7.3, Ar-H), $7.28(2 \mathrm{H}, \mathrm{t}, J$ 7.6, Ar-H), $7.21\left(1 \mathrm{H}, \mathrm{t}, J\right.$ 7.3, Ar-H), $3.89\left(2 \mathrm{H}, \mathrm{d}, J\right.$ 9.9, $\left.\mathrm{SCH}_{2}\right)$, $2.68\left(2 \mathrm{H}, \mathrm{dt}, J 8.7\right.$ and 7.4, $\left.\mathrm{CH}_{2} \mathrm{NH}\right), 1.39(2 \mathrm{H}$, app sx, $J$ 7.4, $\left.\mathrm{CH}_{3} \mathrm{CH}_{2}\right), 0.86\left(3 \mathrm{H}, \mathrm{t}, J\right.$ 7.4, $\left.\mathrm{CH}_{3} \mathrm{CH}_{2}\right) ; \delta_{\mathrm{P}}\left[{ }^{1} \mathrm{H}\right](283 \mathrm{MHz}$; ${ }_{5} \mathrm{CD}_{3} \mathrm{OD}$ ) 23.1 (app qn, $J$ 9.5, NHPS); $\delta_{\mathrm{C}}\left(176 \mathrm{MHz} ; \mathrm{CD}_{3} \mathrm{OD}\right.$ ) $140.2\left(\mathrm{~d},{ }^{3} J_{\mathrm{C}-\mathrm{P}} 6.1, \mathrm{SCH}_{2} \mathrm{C}\right), 128.7,128.2,126.5,43.8\left(\mathrm{CH}_{2} \mathrm{NH}\right)$, 34.6 (d, $\left.{ }^{2} J_{\mathrm{C}-\mathrm{P}} 2.8, \mathrm{SCH}_{2}\right), 24.5\left(\mathrm{~d},{ }^{3} J_{\mathrm{C}-\mathrm{P}} 8.8, \mathrm{CH}_{3} \mathrm{CH}_{2}\right), 10.7$ $\left(\mathrm{CH}_{3} \mathrm{CH}_{2}\right) ; \mathrm{m} / z\left(\mathrm{ES}^{-}\right) 244.05622\left(\mathrm{M}-\mathrm{H} . \mathrm{C}_{10} \mathrm{H}_{15} \mathrm{NO}_{2} \mathrm{PS}\right.$ requires 244.05666).

${ }_{20} 30 \mathbf{a}$<smiles></smiles>

$\delta_{\mathrm{H}}\left(700 \mathrm{MHz} ; \mathrm{CD}_{3} \mathrm{OD}\right) 8.81(1 \mathrm{H}, \mathrm{dd}, J 4.2$ and 1.6, Ar-H), 8.37 ( $1 \mathrm{H}, \mathrm{d}, J 4.3, \mathrm{Ar}-\mathrm{H}), 8.23$ (1 H, dd, $J 8.2$ and 1.4, Ar-H), 7.82 (1 H, d, $J$ 7.0, Ar-H), $7.74(1 \mathrm{H}, \mathrm{d}, J 8.0, \mathrm{Ar}-\mathrm{H}), 7.65(1 \mathrm{H}, \mathrm{td}, J 7.7$ 25 and 1.7, Ar-H), 7.47-7.42 (2 H, m, Ar-H), 7.20 (1 H, d, J 7.8, Ar$\mathrm{H}), 7.17(1 \mathrm{H}, \mathrm{dd}, J 6.9$ and 5.5, Ar-H), $4.50(2 \mathrm{H}, \mathrm{d}, J 10.4$, $\left.\mathrm{SCH}_{2}\right)$, 3.05-2.99 (2 H, m, $\left.\mathrm{CH}_{2} \mathrm{CH}_{2} \mathrm{NH}\right), 2.81(2 \mathrm{H}, \mathrm{t}, J$ 7.2, $\mathrm{CH}_{2} \mathrm{CH}_{2} \mathrm{NH}$ ); $\delta_{\mathrm{P}}\left[{ }^{1} \mathrm{H}\right]\left(283 \mathrm{MHz} ; \mathrm{CD}_{3} \mathrm{OD}\right) 23.6$ (app qn, $J$ 10.1, $\mathrm{NH} P \mathrm{~S}) ; \delta_{\mathrm{C}}\left(176 \mathrm{MHz} ; \mathrm{CD}_{3} \mathrm{OD}\right) 160.0,149.2,148.2,145.8,137.9-$ $30137.8\left(\mathrm{~m},{ }^{3} J_{\mathrm{C}-\mathrm{P}}\right.$ not resolved, $\left.\mathrm{SCH}_{2} \mathrm{C}\right), 137.0,136.6,129.7,128.5$, $126.9,126.1,123.6,121.5,120.9,41.6\left(\mathrm{CH}_{2} \mathrm{NH}\right), 39.1\left(\mathrm{~d},{ }^{3} J_{\mathrm{C}-\mathrm{P}}\right.$ 7.6, $\left.\mathrm{CH}_{2} \mathrm{CH}_{2} \mathrm{NH}\right), 30.2\left(\mathrm{SCH}_{2}\right) ; m / z\left(\mathrm{ES}^{-}\right) 358.0786(\mathrm{M}-\mathrm{H}$. $\mathrm{C}_{17} \mathrm{H}_{17} \mathrm{~N}_{3} \mathrm{O}_{2} \mathrm{PS}$ requires 358.0784). 30c<smiles>CCCSP(=O)([O-])NCCc1ccccn1</smiles>

$\delta_{\mathrm{H}}\left(700 \mathrm{MHz} ; \mathrm{CD}_{3} \mathrm{OD}\right) 8.42(1 \mathrm{H}, \mathrm{ddd}, J 5.0,1.7$ and $0.9, \mathrm{Ar}-\mathrm{H})$, $7.74(1 \mathrm{H}, \mathrm{td}, J 7.7$ and 1.8, Ar-H), $7.37(1 \mathrm{H}, \mathrm{d}, J 7.8, \mathrm{Ar}-\mathrm{H})$, $7.24(1 \mathrm{H}$, ddd, $J$ 7.5, 5.0 and 1.0, Ar-H), $3.22(2 \mathrm{H}, \mathrm{dt}, J 9.8$ and 7.1, $\left.\mathrm{CH}_{2} \mathrm{CH}_{2} \mathrm{NH}\right), 2.98\left(2 \mathrm{H}, \mathrm{t}, J\right.$ 7.1, $\left.\mathrm{CH}_{2} \mathrm{CH}_{2} \mathrm{NH}\right), 2.55(2 \mathrm{H}, \mathrm{dt}$, ${ }_{40} J 10.3$ and 7.3, $\left.\mathrm{SCH}_{2}\right), 1.58\left(2 \mathrm{H}\right.$, app sx, $J$ 7.4, $\left.\mathrm{CH}_{2} \mathrm{CH}_{3}\right), 0.93$ (3 $\left.\mathrm{H}, \mathrm{t}, J 7.4, \mathrm{CH}_{2} \mathrm{CH}_{3}\right) ; \delta_{\mathrm{P}}\left[{ }^{1} \mathrm{H}\right]\left(283 \mathrm{MHz} ; \mathrm{CD}_{3} \mathrm{OD}\right) 24.0$ (app qn, $J$ $10.1, \mathrm{NHPS}) ; \delta_{\mathrm{C}}\left(176 \mathrm{MHz} ; \mathrm{CD}_{3} \mathrm{OD}\right) 159.9,148.2,137.1,123.8$, 121.5, $41.6\left(\mathrm{CH}_{2} \mathrm{CH}_{2} \mathrm{NH}\right), 39.2\left(\mathrm{~d},{ }^{3} \mathrm{~J}_{\mathrm{C}-\mathrm{P}} 8.0, \mathrm{CH}_{2} \mathrm{CH}_{2} \mathrm{NH}\right), 32.1$ ( $\left.\mathrm{SCH}_{2}\right), 23.9$ (d, ${ }^{3} J_{\mathrm{C}-\mathrm{P}}$ 6.4, $\left.\mathrm{CH}_{2} \mathrm{CH}_{3}\right), 12.5\left(\mathrm{CH}_{2} \mathrm{CH}_{3}\right) ; \mathrm{m} / z\left(\mathrm{ES}^{-}\right)$ ${ }_{45} 259.06778\left(\mathrm{M}-\mathrm{H} . \mathrm{C}_{10} \mathrm{H}_{16} \mathrm{~N}_{2} \mathrm{O}_{2} \mathrm{PS}\right.$ requires 259.06756).
$31 \mathbf{a}$<smiles></smiles>

$\delta_{\mathrm{H}}\left(700 \mathrm{MHz} ; \mathrm{CD}_{3} \mathrm{OD}\right) 8.83(1 \mathrm{H}, \mathrm{dd}, J 4.0$ and 1.3, Ar-H), 8.27$8.24(1 \mathrm{H}, \mathrm{m}, \mathrm{Ar}-\mathrm{H}), 7.88(1 \mathrm{H}, \mathrm{d}, J$ 7.0, Ar-H), $7.76(1 \mathrm{H}, \mathrm{d}, J$ 50 8.0, Ar-H), 7.57 (1 H, d, J 7.6, Ar-H), 7.51-7.43 (2 H, m, Ar-H), 7.01-6.98 (1 H, m, Ar-H), 6.95-6.91 (2 H, m, Ar-H), 4.64-4.61 (2 $\left.\mathrm{H}, \mathrm{m}, \mathrm{SCH} \mathrm{H}_{2}\right), 4.30-4.25(1 \mathrm{H}, \mathrm{m}, \mathrm{C} H \mathrm{NH}), 2.70-2.55(2 \mathrm{H}, \mathrm{m}, 3-$ $\left.\mathrm{CH}_{2}\right), 1.95-1.87(1 \mathrm{H}, \mathrm{m}, \mathrm{CH} H), 1.79-1.71(1 \mathrm{H}, \mathrm{m}, \mathrm{CH} H), 1.68-$ $1.55\left(2 \mathrm{H}, \mathrm{m}, \mathrm{CH}_{2}\right) ; \delta_{\mathrm{P}}\left[{ }^{1} \mathrm{H}\right]\left(283 \mathrm{MHz} ; \mathrm{CD}_{3} \mathrm{OD}\right) 21.3$ (app q, $J$ 55 10.3, NHPS); $\delta_{\mathrm{C}}\left(176 \mathrm{MHz} ; \mathrm{CD}_{3} \mathrm{OD}\right) 149.2,146.0,140.0-139.8$ $\left(\mathrm{m},{ }^{3} J_{\mathrm{C}-\mathrm{P}}\right.$ not resolved, CCHNH), 138.0-137.9 (m, ${ }^{3} J_{\mathrm{C}-\mathrm{P}}$ not resolved, $\left.\mathrm{SCH}_{2} \mathrm{C}\right), 136.8,136.5,129.7,128.9,128.6,128.0$, $126.9,126.2,125.9,125.2,120.9,49.7(\mathrm{CHNH}), 31.9,30.3(\mathrm{~d}$, $\left.{ }^{3} J_{\mathrm{C}-\mathrm{P}} \quad 2.6\right), 29.0 \quad\left(\mathrm{SCH}_{2}\right), 19.7 ; \mathrm{m} / z \quad\left(\mathrm{ES}^{-}\right) \quad 383.0987 \quad(\mathrm{M}-\mathrm{H}$. ${ }_{60} \mathrm{C}_{20} \mathrm{H}_{20} \mathrm{~N}_{2} \mathrm{O}_{2}$ PS requires 383.0988).

31c<smiles>CCCSP(=O)([O-])NC1CCCc2ccccc21</smiles>

$\delta_{\mathrm{H}}\left(700 \mathrm{MHz} ; \mathrm{CD}_{3} \mathrm{OD}\right) 7.63(1 \mathrm{H}, \mathrm{d}, J$ 7.2, Ar-H), 7.09-7.03 $(2 \mathrm{H}$, $\mathrm{m}, \mathrm{Ar}-\mathrm{H}), 6.99$ (1 H, d, J 7.3, Ar-H), 4.34-4.29 (1 H, m, CHNH), ${ }_{65}$ 2.80-2.64 (4 H, m, 3-CH $\mathrm{CH}_{2}$ and $\left.\mathrm{SCH}_{2}\right), 2.11-2.04\left(1 \mathrm{H}, \mathrm{m}, 4-\mathrm{CH}_{2}\right)$, 1.96-1.89 (1 H, m, 4-CH $\left.\mathrm{CH}_{2}\right), 1.89-1.82\left(1 \mathrm{H}, \mathrm{m}, 2-\mathrm{CH}_{2}\right), 1.78-1.62$ $\left(4 \mathrm{H}, \mathrm{m}, 2-\mathrm{CH}_{2}\right.$ and $\left.\mathrm{CH}_{2} \mathrm{CH}_{3}\right), 0.99\left(3 \mathrm{H}, \mathrm{t}, \mathrm{J} \mathrm{7.4}, \mathrm{CH}_{2} \mathrm{CH}_{3}\right)$; $\delta_{\mathrm{P}}\left[{ }^{1} \mathrm{H}\right]\left(283 \mathrm{MHz} ; \mathrm{CD}_{3} \mathrm{OD}\right)$ 22.2-22.0 (m, NHPS); $\delta_{\mathrm{C}}(176 \mathrm{MHz}$; $\left.\mathrm{CD}_{3} \mathrm{OD}\right)$ 140.1-140.0 (m, CCHNH), 136.7, 128.9, 128.1, 126.0, $70125.2,49.7(\mathrm{CHNH}), 32.5(2-\mathrm{CH}), 32.3\left(\mathrm{SCH}_{2}\right), 29.0(4-\mathrm{CH})$, 23.9 (d, $\left.{ }^{3} J_{\mathrm{C}-\mathrm{P}} 7.0, \mathrm{CH}_{2} \mathrm{CH}_{3}\right), 19.8(3-\mathrm{CH}), 12.6\left(\mathrm{CH}_{2} \mathrm{CH}_{3}\right) ; \mathrm{m} / z$ (ES $\left.{ }^{-}\right) 284.08826$ (M-H. $\mathrm{C}_{13} \mathrm{H}_{19} \mathrm{NO}_{2} \mathrm{PS}$ requires).

32a<smiles></smiles>

${ }_{75} \delta_{\mathrm{H}}\left(700 \mathrm{MHz} ; \mathrm{CD}_{3} \mathrm{OD}\right) 8.86(1 \mathrm{H}, \mathrm{dd}, J 4.2$ and $1.7, \mathrm{Ar}-\mathrm{H}), 8.26$ $(1 \mathrm{H}, \mathrm{dd}, J 8.2$ and 1.7, Ar-H), $7.87(1 \mathrm{H}, \mathrm{d}, J 7.0, \mathrm{Ar}-\mathrm{H}), 7.78$ (1 $\mathrm{H}, \mathrm{d}, J$ 8.2, Ar-H), 7.52-7.46 (2 H, m, Ar-H), $4.54(2 \mathrm{H}, \mathrm{d}, J 10.8$, $\left.\mathrm{SCH}_{2}\right), 3.60\left(4 \mathrm{H}, \mathrm{t}, J 4.6, \mathrm{O}\left(\mathrm{CH}_{2}\right)_{2}\right), 2.67(2 \mathrm{H}, \mathrm{dt}, J 9.3$ and 7.0, $\left.\mathrm{PNHCH}_{2}\right), 2.30\left(4 \mathrm{H}\right.$, br s, $\left.\left(\mathrm{CH}_{2}\right)_{2} \mathrm{~N}\right), 2.24-2.20\left(2 \mathrm{H}, \mathrm{m}, \mathrm{NCH}_{2}\right)$, ${ }_{80}$ 1.50-1.44 (2 H, m, $\left.\mathrm{CH}_{2} \mathrm{CH}_{2} \mathrm{CH}_{2}\right) ; \delta_{\mathrm{P}}\left[{ }^{1} \mathrm{H}\right]\left(283 \mathrm{MHz} ; \mathrm{CD}_{3} \mathrm{OD}\right) 23.8$ (app qn, $J 10.1, \mathrm{NH} P \mathrm{~S}) ; \delta_{\mathrm{C}}\left(176 \mathrm{MHz} ; \mathrm{CD}_{3} \mathrm{OD}\right) 149.2,145.9$, 138.2-138.0 (m, $\left.\mathrm{SCH}_{2} \mathrm{C}\right), 136.6,129.6,128.5,126.9,126.1$, 121.0, $66.2\left(\mathrm{O}\left(\mathrm{CH}_{2}\right)_{2}\right), 56.6\left(\mathrm{NCH}_{2}\right), 53.3\left(\left(\mathrm{CH}_{2}\right)_{2} \mathrm{~N}\right), \quad 40.2$ $\left(\mathrm{CH}_{2} \mathrm{NH}\right), 29.9\left(\mathrm{SCH}_{2}\right), 27.3$ (d, $\left.{ }^{3} J_{\mathrm{C}-\mathrm{P}} 7.5, \mathrm{CH}_{2} \mathrm{CH}_{2} \mathrm{NHP}\right) ; \mathrm{m} / z$ ${ }_{85}\left(\mathrm{ES}^{-}\right) 380.1202\left(\mathrm{M}-\mathrm{H} . \mathrm{C}_{17} \mathrm{H}_{23} \mathrm{~N}_{3} \mathrm{O}_{3}\right.$ PS requires 380.1203$)$. $32 \mathrm{c}$ 
<smiles>CCCSP(=O)([O-])NCCCN1CCOCC1</smiles>

$\delta_{\mathrm{H}}\left(700 \mathrm{MHz} ; \mathrm{CD}_{3} \mathrm{OD}\right)$ 3.70-3.66 $\left(4 \mathrm{H}, \mathrm{m}, \mathrm{O}\left(\mathrm{CH}_{2}\right)_{2}\right), 2.91(2 \mathrm{H}$, $\mathrm{dt}, J 9.6$ and $\left.6.8, \mathrm{SCH}_{2}\right), 2.63\left(2 \mathrm{H}, \mathrm{dt}, J 10.3\right.$ and $\left.7.3, \mathrm{CH}_{2} \mathrm{NH}\right)$, $2.46\left(4 \mathrm{H}\right.$, br s, $\left.\left(\mathrm{CH}_{2}\right)_{2} \mathrm{~N}\right), 2.44-2.40\left(2 \mathrm{H}, \mathrm{m}, \mathrm{NCH}_{2}\right), 1.75-1.65(2$ $\left.{ }_{5} \mathrm{H}, \mathrm{m}, \mathrm{CH}_{2} \mathrm{CH}_{2} \mathrm{CH}_{2}\right), 1.65-1.60\left(2 \mathrm{H}, \mathrm{m}, \mathrm{CH}_{2} \mathrm{CH}_{3}\right), 0.97(3 \mathrm{H}, \mathrm{t}, \mathrm{J}$ 7.4, $\left.\mathrm{CH}_{2} \mathrm{CH}_{3}\right) ; \delta_{\mathrm{P}}\left[{ }^{1} \mathrm{H}\right]\left(283 \mathrm{MHz} ; \mathrm{CD}_{3} \mathrm{OD}\right.$ ) 24.2 (app qn, $J$ 9.9, $\mathrm{NHPS}) ; \delta_{\mathrm{C}}\left(176 \mathrm{MHz} ; \mathrm{CD}_{3} \mathrm{OD}\right)$ details for major conformer 66.3 $\left(\mathrm{O}\left(\mathrm{CH}_{2}\right)_{2}\right), 56.8\left(\mathrm{NCH}_{2}\right), 53.4\left(\left(\mathrm{CH}_{2}\right)_{2} \mathrm{~N}\right), 40.2\left(\mathrm{CH}_{2} \mathrm{NH}\right), 32.1$ $\left(\mathrm{SCH}_{2}\right), 27.8-27.4\left(\mathrm{~m}, \mathrm{CH}_{2} \mathrm{CH}_{2} \mathrm{CH}_{2}\right), 24.2-23.8\left(\mathrm{~m}, \mathrm{CH}_{2} \mathrm{CH}_{3}\right)$, 10 12.7-12.5 (m, $\left.\mathrm{CH}_{2} \mathrm{CH}_{3}\right) ; \quad \mathrm{m} / \mathrm{z} \quad\left(\mathrm{ES}^{-}\right) \quad 281.10967 \quad(\mathrm{M}-\mathrm{H}$. $\mathrm{C}_{10} \mathrm{H}_{22} \mathrm{~N}_{2} \mathrm{O}_{3} \mathrm{PS}$ requires 281.10943).

33a

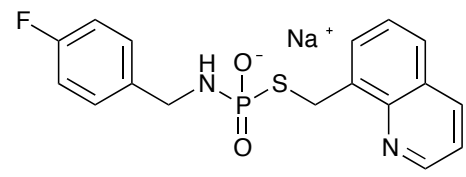

$\delta_{\mathrm{H}}\left(700 \mathrm{MHz} ; \mathrm{CD}_{3} \mathrm{OD}\right) 8.79(1 \mathrm{H}, \mathrm{dd}, J 4.2$ and $1.7, \mathrm{Ar}-\mathrm{H}), 8.23$ ${ }_{15}(1 \mathrm{H}, \mathrm{dd}, J 8.2$ and 1.7, Ar-H), $7.81(1 \mathrm{H}, \mathrm{d}, J$ 7.0, Ar-H), 7.74 (1 $\mathrm{H}, \mathrm{d}, J$ 8.2, Ar-H), 7.47-7.44 (1 H, m, Ar-H), 7.42 (1 H, dd, $J 8.2$ and 4.2, Ar-H), 7.16-7.12 (2 H, m, Ar-H), $6.98(2 \mathrm{H}, \mathrm{t}, J$ 8.8, Ar$\mathrm{H}), 4.54\left(2 \mathrm{H}, \mathrm{d}, J 11.1, \mathrm{CH}_{2} \mathrm{NH}\right), 3.73\left(2 \mathrm{H}, \mathrm{d}, J\right.$ 8.3, $\mathrm{SCH} \mathrm{H}_{2}$; $\delta_{\mathrm{P}}\left[{ }^{1} \mathrm{H}\right]\left(283 \mathrm{MHz} ; \mathrm{CD}_{3} \mathrm{OD}\right) 23.6-23.4(\mathrm{~m}, \mathrm{NHPS}) ; \delta_{\mathrm{F}}(376 \mathrm{MHz}$; $\left.{ }_{20} \mathrm{CD}_{3} \mathrm{OD}\right)-(118.8-119.0)(\mathrm{m}, \mathrm{Ar}-F) ; \delta_{\mathrm{C}}\left(176 \mathrm{MHz} ; \mathrm{CD}_{3} \mathrm{OD}\right) 162.4$, 149.2, 145.8, 138.1-137.9 (m, $\left.\mathrm{PSCH}_{2} \mathrm{C}\right), 137.0-136.8$ (m, $\mathrm{CCH}_{2} \mathrm{NHP}$ ), 136.6, 129.7, 129.0 (d, $\left.{ }^{3} J_{\mathrm{C}-\mathrm{F}}, 8.0\right), 128.6,126.9$, 126.1, 121.0, $114.2\left(\mathrm{~d},{ }^{2} J_{\mathrm{C}-\mathrm{F}}, 21.4\right), 45.0\left(\mathrm{CH}_{2} \mathrm{NH}\right), 29.8\left(\mathrm{SCH}_{2}\right)$; $\mathrm{m} / \mathrm{z}\left(\mathrm{ES}^{-}\right) 361.0583\left(\mathrm{M}-\mathrm{H} . \mathrm{C}_{17} \mathrm{H}_{15} \mathrm{~N}_{2} \mathrm{O}_{2}\right.$ FPS requires 361.0581). ${ }_{25} 33 \mathbf{c}$

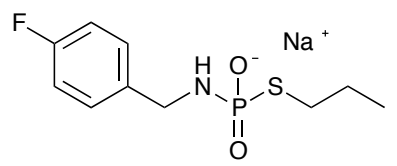

$\delta_{\mathrm{H}}\left(700 \mathrm{MHz} ; \mathrm{CD}_{3} \mathrm{OD}\right)$ 7.41-4.37 $(2 \mathrm{H}, \mathrm{m}, \mathrm{Ar}-\mathrm{H}), 7.00-6.95(2 \mathrm{H}$, $\mathrm{m}, \mathrm{Ar}-\mathrm{H}), 4.02\left(2 \mathrm{H}, \mathrm{d}, J\right.$ 9.4, $\left.\mathrm{CH}_{2} \mathrm{NH}\right), 2.61(2 \mathrm{H}, \mathrm{dt}, J 10.3$ and 7.3, $\mathrm{SCH}_{2}$ ), 1.61 (2 H, app sx, $\left.J 7.4, \mathrm{CH}_{2} \mathrm{CH}_{3}\right), 0.95$ (3 H, t, $J$ 7.4, $\left.{ }_{30} \mathrm{CH}_{2} \mathrm{CH}_{3}\right) ; \delta_{\mathrm{P}}\left[{ }^{1} \mathrm{H}\right]\left(283 \mathrm{MHz} ; \mathrm{CD}_{3} \mathrm{OD}\right.$ ) 23.8 (app qn, $J 9.8 \mathrm{NHPS}$ ); $\delta_{\mathrm{F}}\left(376 \mathrm{MHz} ; \mathrm{CD}_{3} \mathrm{OD}\right)-(118.9-119.1)(\mathrm{m}, \mathrm{Ar}-F) ; \delta_{\mathrm{C}}(176 \mathrm{MHz}$; $\left.\mathrm{CD}_{3} \mathrm{OD}\right) 161.8$ (d, $\left.J_{\mathrm{C}-\mathrm{F}} 242.5, \mathrm{FC}\right), 137.4$ (d, $\left.{ }^{3} J_{\mathrm{C}-\mathrm{P}} 8.0, C \mathrm{CH}_{2} \mathrm{NH}\right)$, $129.0\left(\mathrm{~d},{ }^{3} J_{\mathrm{C}-\mathrm{F}}, 8.0,3-\mathrm{CH}\right.$ and $\left.5-\mathrm{CH}\right), 114.2\left(\mathrm{~d},{ }^{2} J_{\mathrm{C}-\mathrm{F}}, 21.5,2-\mathrm{CH}\right.$ and $6-\mathrm{CH}), 45.0\left(\mathrm{CH}_{2} \mathrm{NH}\right), 32.1\left(\mathrm{SCH}_{2}\right), 24.0\left(\mathrm{~d},{ }^{3} J_{\mathrm{C}-\mathrm{P}} \quad 6.4\right.$, $\left.{ }_{35} \mathrm{CH}_{2} \mathrm{CH}_{3}\right), 12.5\left(\mathrm{CH}_{2} \mathrm{CH}_{3}\right) ; \mathrm{m} / z\left(\mathrm{ES}^{-}\right) 262.04744(\mathrm{M}-\mathrm{H}$. $\mathrm{C}_{10} \mathrm{H}_{14} \mathrm{NO}_{2}$ FPS requires 262.04724)

34

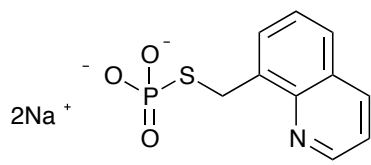

$\delta_{\mathrm{H}}\left(500 \mathrm{MHz} ; \mathrm{CD}_{3} \mathrm{OD}\right)$ 8.87-8.84 $(1 \mathrm{H}, \mathrm{m}, \mathrm{Ar}-\mathrm{H}), 8.29-8.25(1 \mathrm{H}$, $40 \mathrm{~m}, \mathrm{Ar}-\mathrm{H}), 8.00-7.96$ (1 H, m, Ar-H), 7.77-7.74 (1 H, m, Ar-H), 7.53-7.44 (2 H, m, Ar-H), 4.66-4.62 (2 H, m, SCH$) ; \delta_{\mathrm{P}}\left[{ }^{1} \mathrm{H}\right](283$
$\left.\mathrm{MHz} ; \mathrm{CD}_{3} \mathrm{OD}\right) 18.1$ (t, $\left.{ }^{3} J_{\mathrm{H}-\mathrm{P}} 6.9, \mathrm{NHPS}\right) ; \delta_{\mathrm{C}}\left(125 \mathrm{MHz} ; \mathrm{CD}_{3} \mathrm{OD}\right)$ $149.1,146.1,138.8$ (d, $\left.{ }^{3} J_{\mathrm{C}-\mathrm{P}} 7.0, \mathrm{SCH}_{2} \mathrm{C}\right), 136.7,130.1,128.5$, $126.4,126.3,120.7,43.4\left(\mathrm{CH}_{2} \mathrm{NH}\right) ; \mathrm{m} / z\left(\mathrm{ES}^{-}\right) 254.0047(\mathrm{M}-\mathrm{H}$. ${ }_{45} \mathrm{C}_{10} \mathrm{H}_{9} \mathrm{NO}_{2} \mathrm{PS}$ requires 254.0046).

\section{Acknowledgements}

We thank Durham University (MT), EPSRC (FLC), Wolfson Small Grants Scheme (SLC/PWD) and the Royal Society (DRWH) for funding. In addition, we are grateful to Drs Alan ${ }_{50}$ Kenwright and Ian Cummins for NMR and MS support.

\section{Notes and references}

${ }^{a}$ Department of Chemistry, Science Laboratories, Durham University, South Road, Durham, DH1 3LE, United Kingdom.

${ }^{b}$ School of Medicine and Health, Queen's Campus, Stockton-on-Tees,

${ }_{55}$ TS17 6BH, United Kingdom; and School of Biological and Biomedical Sciences, Science Laboratories, Durham University, South Road,

Durham, DH1 3LE, United Kingdom.

E-mail:d.r.w.hodgson@durham.ac.uk

$\dagger$ Electronic Supplementary Information (ESI) available: [details of

${ }_{60}$ kinetic studies; ${ }^{31} \mathrm{P} \mathrm{NMR},{ }^{1} \mathrm{H},{ }^{31} \mathrm{P}$ and ${ }^{13} \mathrm{C}$ NMR spectra of reported compounds; summary of biological testing data]. See DOI: $10.1039 / \mathrm{b} 000000 \mathrm{x} /$

1. S. R. Das, R. Fong and J. A. Piccirilli, Curr. Opin. Chem. Biol., 2005, 9, 585-593.

2. D. Herschlag, J. A. Piccirilli and T. R. Cech, Biochemistry, 1991, 30, 4844-4854.

3. M. Mag and J. W. Engels, Tetrahedron, 1994, 50, 10225-10234.

4. M. Mag, R. Schmidt and J. W. Engels, Tetrahedron Lett., 1992, 33, 7319-7322.

5. S. Gryaznov and J. K. Chen, J. Am. Chem. Soc., 1994, 116, 31433144.

6. J. K. Chen, R. G. Schultz, D. H. Lloyd and S. M. Gryaznov, Nucleic Acids Res., 1995, 23, 2661-2668.

75 7. I. Kers, J. Stawinski and A. Kraszewski, Tetrahedron Lett., 1998, 39, 1219-1222.

8. S. M. Gryaznov and N. I. Sokolova, Tetrahedron Lett., 1990, 31, 3205-3208.

9. M. Ora, K. Mattila, T. Lonnberg, M. Oivanen and H. Lonnberg, $J$. Am. Chem. Soc., 2002, 124, 14364-14372.

10. M. Ora, M. Murtola, S. Aho and M. Oivanen, Org. Biomol. Chem., 2004, 2, 593-600.

11. M. Trmčić and D. R. W. Hodgson, Chem. Commun., 2011, 47, 61566158.

85 12. R. J. Delley, A. C. Donoghue and D. R. W. Hodgson, J. Org. Chem., 2012, 77, 5829-5831.

13. D. Williamson, M. J. Cann and D. R. W. Hodgson, Chem. Commun., 2007, 5096-5098.

14. D. Williamson and D. R. W. Hodgson, Org. Biomol. Chem., 2008, 6, 1056-1062.

15. World Health Organization: Neglected Tropical Diseases, http://www.who.int/neglected diseases/diseases/en/, accessed December 2012.

16. M. Lasker, C. D. Bui, P. G. Besant, K. Sugawara, P. Thai, G. Medzihradszky and C. W. Turck, Prot. Sci., 1999, 8, 2177-2185.

17. M. C. Pirrung, K. D. James and V. S. Rana, J. Org. Chem., 2000, 65, 8448-8453.

18. T. Ruman, K. Dlugopolska, A. Jurkiewicz, D. Rut, T. Fraczyk, J. Ciesla, A. Les, Z. Szewczuk and W. Rode, Bioorg. Chem., 2010, 38, 74-80.

19. J. L. Norcliffe, L. P. Conway and D. R. W. Hodgson, Tetrahedron Lett., 2011, 52, 2730-2732.

20. M. Trmčić and D. R. W. Hodgson, Beilstein J. Org. Chem., 2010, 6, 732-741.

105 21. X. H. Duan, B. Maji and H. Mayr, Org. Biomol. Chem., 2011, 9, 8046-8050. 
22. L. E. da Silva, A. C. Joussef, L. K. Pacheco, D. G. da Silva, M. Steindel and R. A. Rebelo, Bioorg. Med. Chem., 2007, 15, 75537560 .

23. L. E. da Silva, A. C. Joussef, L. K. Pacheco, D. G. da Silva, M. Steindel, R. A. Rebelo and B. Schmidt, Bioorg. Med. Chem., 2008, 16, 7079-7079.

24. F. L. Chadbourne, C. Raleigh, H. Z. Ali, P. W. Denny and S. L. Cobb, J. Peptide Sci., 2011, 17, 751-755.

25. P. Brear, G. R. Freeman, M. C. Shankey, M. Trmčić and D. R. W. Hodgson, Chem. Commun., 2009, 4980-4981.

26. D. K. Dean, Synthetic Commun., 2002, 32, 1517-1521.

27. M. Kolb, C. Danzin, J. Barth and N. Claverie, J. Med. Chem., 1982, $25,550-556$. 